\title{
Power Transfer Potential to the Southeast in Response to a Renewable Portfolio Standard: Interim Report 1
}

March 2009

Prepared by

Stanton W. Hadley - ORNL

Thomas Key - EPRI 


\title{
DOCUMENT AVAILABILITY
}

Reports produced after January 1, 1996, are generally available free via the U.S. Department of Energy (DOE) Information Bridge:

Web site: http://www.osti.gov/bridge

Reports produced before January 1, 1996, may be purchased by members of the public from the following source:

\author{
National Technical Information Service \\ 5285 Port Royal Road \\ Springfield, VA 22161 \\ Telephone: 703-605-6000 (1-800-553-6847) \\ TDD: 703-487-4639 \\ Fax: 703-605-6900 \\ E-mail: info@ntis.fedworld.gov \\ Web site: http://www.ntis.gov/support/ordernowabout.htm
}

Reports are available to DOE employees, DOE contractors, Energy Technology Data Exchange (ETDE) representatives, and International Nuclear Information System (INIS) representatives from the following source:

Office of Scientific and Technical Information

P.O. Box 62

Oak Ridge, TN 37831

Telephone: 865-576-8401

Fax: 865-576-5728

E-mail: reports@adonis.osti.gov

Web site: http://www.osti.gov/contact.html

\begin{abstract}
This report was prepared as an account of work sponsored by an agency of the United States Government. Neither the United States government nor any agency thereof, nor any of their employees, makes any warranty, express or implied, or assumes any legal liability or responsibility for the accuracy, completeness, or usefulness of any information, apparatus, product, or process disclosed, or represents that its use would not infringe privately owned rights. Reference herein to any specific commercial product, process, or service by trade name, trademark, manufacturer, or otherwise, does not necessarily constitute or imply its endorsement, recommendation, or favoring by the United States Government or any agency thereof. The views and opinions of authors expressed herein do not necessarily state or reflect those of the United States Government or any agency thereof.
\end{abstract}




\title{
Power Transfer Potential to the Southeast in Response to a Renewable Portfolio Standard: Interim Report 1
}

\author{
Stanton W. Hadley - ORNL
}

Thomas Key - EPRI

March 2009

OAK RIDGE NATIONAL LABORATORY

Oak Ridge, Tennessee 37831

managed by

UT-BATTELLE, LLC

for the

U.S. DEPARTMENT OF ENERGY

under contract No. DE-AC05-00OR22725 



\section{CONTENTS}

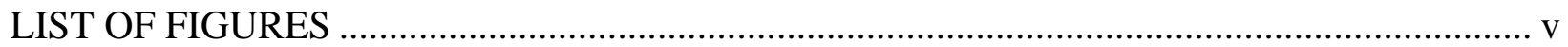

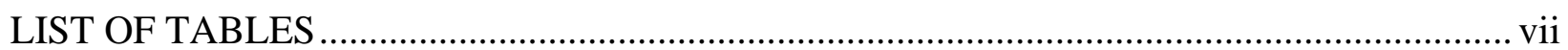

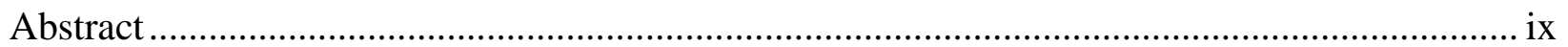

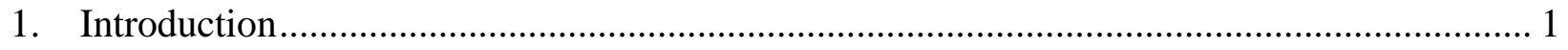

2. Regional Renewable Deployment Estimates ......................................................... 5

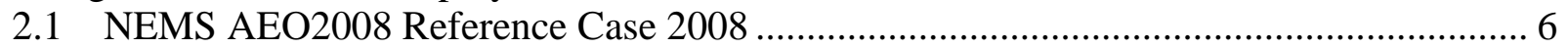

2.2 NEMS AEO2008 Reference Case for 2020........................................................ 7

2.3 Requirements to meet a Federal RPS................................................................... 8

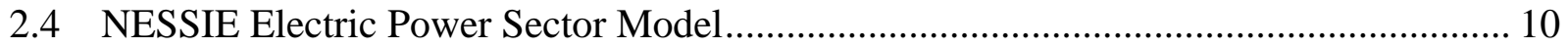

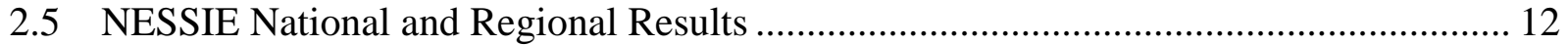

3. Inter-Regional Transmission and Renewable Generation ................................................. 17

3.1 Transfer Capabilities from NEMS ..................................................................... 17

3.2 Current year import/exports from NEMS ......................................................... 19

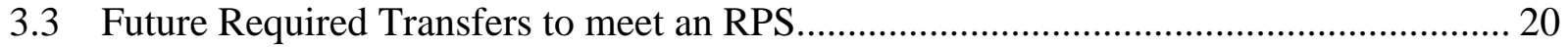

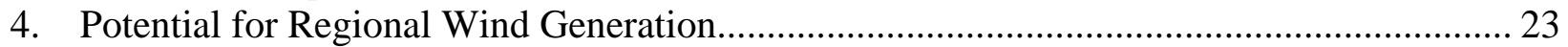

5. Conclusions and Next Steps................................................................................ 25

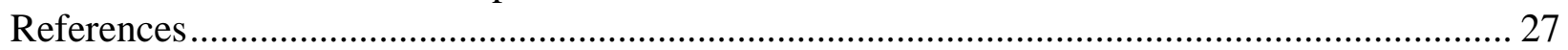





\section{LIST OF FIGURES}

Figure 1. States with RPS policies [Source: Pew Center on Global Climate Change 1-2009] 1

Figure 2. New transmission lines required under 20\% Wind by 2030 scenario (EERE 2008) 3

Figure 3. Regions used by EIA NEMS and EPRI NESSIE 5

Figure 4. Renewable energy generation as a percentage of total generation in $2008 \quad 6$

$\begin{array}{ll}\text { Figure 5. } 2008 \% \text { Renewable generation not including hydro or municipal waste } & 7\end{array}$

Figure $6.2020 \%$ Renewable generation not including hydro or municipal waste 8

Figure 7. Additional generation needed in each region to meet a 15\% RPS in $2020 \quad 9$

Figure 8. Additional capacity needed to meet 15\% RSP with a 33\% capacity factor 9

Figure 9. Relations Between NEMS and NESSIE (Source: EPRI) 11

Figure 10. Base Case US Electricity Generation (1.4\% growth) 13

Figure 11. Base Case Capacity Additions Each 5-year Period 13

Figure 12. Base Case Generation by Renewable Energy as Percent of Total Generation 14

Figure 13. Regional Renewable Generation as \% of Total Generation $2030 \quad 15$

Figure 14. 2008 Inter-Regional Transmission Capacities after planned outside regional $\begin{array}{lr}\text { generation subtracted } & 18\end{array}$

Figure 15. 2020 Planned Inter-Regional Transmission Capacity within NEMS (after planned outside regional generation subtracted)

Figure 16. 2020 Planned Transmission Capacity minus outside generation and planned contract trades

Figure 17. Inter-Regional Imports and Exports in $2008 \quad 20$

Figure 18. NESSIE Generation Mix and Expected Generation Capacity by Region in $2030 \quad 20$

Figure 19. NESSIE result showing needed regional transfers of renewable energy to meet a $20 \%$ RPS in 2030, based on the renewable energy required in each region. 21

Figure 20. Potential wind capacity by region for Wind Classes 5-7 23

Figure 21. Potential wind capacity by region for Wind Classes 4-7 24 



\section{LIST OF TABLES}

Table 1. Renewable Energy Estimate by State based on RPS Requirements and Energy Sales, * states with renewable capacity requirements [Source: EPRI RPS estimate, 12/2008] .......... 2

Table 2. 2008 Generation by technology in the AEO2008 Reference Case (TWh) .................... 6

Table 3. 2008 Regional generation (by amount and \%) and renewable \% of generation.............. 7

Table 4. Regional Comparison of Wind Resources and Wind Deployment. ............................ 24 



\begin{abstract}
The power transfer potential for bringing renewable energy into the Southeast in response to a renewable portfolio standard (RPS) will depend not only on available transmission capacity but also on electricity supply and demand factors. This interim report examines how the commonly used EIA NEMS and EPRI NESSIE energy equilibrium models are considering such power transfers. Using regional estimates of capacity expansion and demand, a base case for 2008, 2020 and 2030 are compared relative to generation mix, renewable deployments, planned power transfers, and meeting RPS goals. The needed amounts of regional renewable energy to comply with possible RPS levels are compared to inter-regional transmission capacities to establish a baseline available for import into the Southeast and other regions. Gaps in the renewable generation available to meet RPS requirements are calculated. The initial finding is that the physical capability for transferring renewable energy into the SE is only about $10 \%$ of what would be required to meet a 20\% RPS. Issues that need to be addressed in future tasks with respect to modeling are the current limitations for expanding renewable capacity and generation in one region to meet the demand in another and the details on transmission corridors required to deliver the power.
\end{abstract}





\section{Introduction}

A renewable portfolio standard (RPS) requires that affected electricity suppliers provide a specified portion of their sales from renewable technologies. The production can either be by the supplier itself or from renewable energy developers who are issued certified renewable energy credits (RECs) for their production. This can create a market for renewable energy at a premium over the commodity generation of electricity from all sources.

As of end of 2008, 34 states and the District of Columbia have implemented RPS policies although with different target dates, percentage requirements, and types of technologies considered as renewable. All the states have set a time horizon for phasing in RPS requirements. Some states, such as New York, include large hydroelectric generation in their mix of renewables, but many do not. Some, such as Pennsylvania, create two tiers of qualifying renewables with different percentages for each. Some states limit the geographic scope where the renewable energy must be generated within their state or region, while others may allow production from anywhere in the country to be counted, as long as the utility purchases the RECs. Texas and Iowa have set the amount of capacity from renewable sources rather than a percentage of electricity sales.

Figure 1 shows the states with RPS policies, both mandatory targets and goals to be met. Table 1 estimates the total renewable energy generation and the capacity by 2020 based on the states RPS goals. This calculation assumes that goals will be met, and not exceeded based on each state's planning horizon and target date. It also removes the existing hydro in NY and in CA from the state totals in 2020. Capacity factors are estimated based on the expected mix of the renewable generation considering differences between wind, solar, geothermal and biomass.

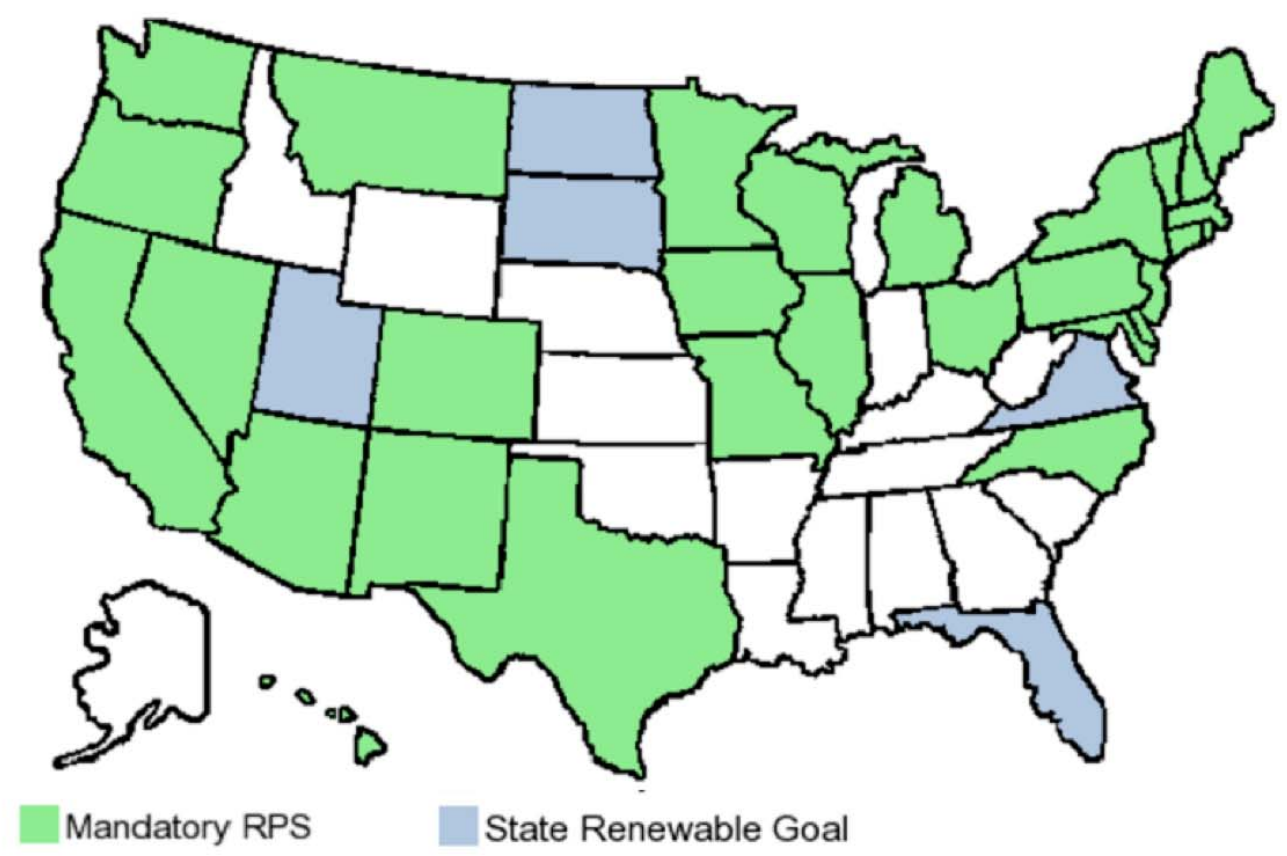

Figure 1. States with RPS policies [Source: Pew Center on Global Climate Change 1-2009] 
Table 1. Renewable Energy Estimate by State based on RPS Requirements and Energy Sales, * states with renewable capacity requirements [Source: EPRI RPS estimate, 12/2008]

\begin{tabular}{|c|c|c|c|c|c|c|c|c|}
\hline & State & RPS \% & $\begin{array}{c}\text { Solar } \\
\%\end{array}$ & $\begin{array}{c}\text { Target } \\
\text { Date }\end{array}$ & $\begin{array}{l}\text { Additions } \\
\text { up to } 2020\end{array}$ & $\begin{array}{c}\text { RPS MWH in } \\
2020\end{array}$ & $\begin{array}{c}\text { RPS MW } \\
\text { (W/O Hydro) }\end{array}$ & $\begin{array}{c}\text { Capacity } \\
\text { Factor }\end{array}$ \\
\hline 1 & $\mathrm{CA}$ & 20 & 4 & 2010 & 1.00 & $50,849,901$ & 7,208 & 0.5 \\
\hline 2 & NY & 25 & 0.15 & 2013 & 1.00 & $37,536,893$ & 3,249 & 0.4 \\
\hline 3 & FL & 20 & & 2020 & 1.00 & $44,995,402$ & 7,338 & 0.7 \\
\hline 4 & PA & 18 & 0.5 & 2020 & 1.00 & $26,689,129$ & 7,617 & 0.4 \\
\hline 5 & IL & 25 & & 2025 & 0.71 & $25,585,803$ & 7,302 & 0.4 \\
\hline 6 & $T X^{*}$ & 0 & $.5 \mathrm{GW}$ & 2015 & 1.00 & $22,355,520$ & 6,380 & 0.4 \\
\hline 7 & MI & 10 & & 2015 & 1.00 & $11,044,456$ & 2,522 & 0.5 \\
\hline 8 & NJ & 22.5 & 0.3 & 2021 & 0.92 & $17,009,338$ & 4,854 & 0.4 \\
\hline 9 & NC & 12.5 & 0.2 & 2021 & 0.92 & $14,807,928$ & 4,226 & 0.4 \\
\hline 10 & $\mathrm{OH}$ & 12.5 & & 2025 & 0.71 & $14,133,203$ & 4,033 & 0.4 \\
\hline 11 & MN & 30 & & 2025 & 0.71 & $13,980,505$ & 3,990 & 0.4 \\
\hline 12 & WA & 15 & & 2020 & 1.00 & $12,513,780$ & 3,571 & 0.4 \\
\hline 13 & MO & 15 & 2 & 2020 & 1.00 & $12,141,074$ & 3,465 & 0.4 \\
\hline 14 & WI & 10 & & 2015 & 1.00 & $7,033,568$ & 2,007 & 0.4 \\
\hline 15 & VA & 12 & & 2022 & 0.86 & $11,195,954$ & 3,195 & 0.4 \\
\hline 16 & NV & 20 & 1 & 2015 & 1.00 & $6,500,126$ & 1,855 & 0.4 \\
\hline 17 & $\mathrm{CO}$ & 20 & 0.8 & 2020 & 1.00 & $9,670,647$ & 2,760 & 0.4 \\
\hline 18 & OR & 25 & & 2025 & 0.71 & $8,191,631$ & 2,338 & 0.4 \\
\hline 19 & CT & 23 & & 2020 & 1.00 & $7,611,857$ & 2,172 & 0.4 \\
\hline 20 & $\mathbf{A Z}$ & 15 & 4.5 & 2025 & 0.71 & $7,347,249$ & 2,097 & 0.4 \\
\hline 21 & MD & 9.5 & & 2022 & 0.86 & $5,566,896$ & 908 & 0.7 \\
\hline 22 & NM & 20 & & 2020 & 1.00 & $4,127,790$ & 1,178 & 0.4 \\
\hline 23 & UT & 20 & & 2025 & 0.71 & $3,529,482$ & 1,007 & 0.4 \\
\hline 24 & MT & 15 & & 2015 & 1.71 & $3,465,987$ & 989 & 0.4 \\
\hline 25 & DE & 20 & 2 & 2019 & 1.09 & $2,648,026$ & 605 & 0.5 \\
\hline 26 & MA & 4 & & 2020 & 1.00 & $2,289,104$ & 653 & 0.4 \\
\hline 27 & HI & 20 & & 2020 & 1.00 & $2,107,782$ & 481 & 0.5 \\
\hline 28 & ND & 10 & & 2015 & 1.00 & $1,083,999$ & 309 & 0.4 \\
\hline 29 & SD & 10 & & 2015 & 1.00 & 981,102 & 280 & 0.4 \\
\hline 30 & ME & 10 & & 2017 & 1.00 & $1,236,288$ & 353 & 0.4 \\
\hline 31 & VT & 20 & & 2017 & 1.00 & $1,176,611$ & 336 & 0.4 \\
\hline 32 & NH & 16 & 0.3 & 2025 & 0.71 & $1,269,982$ & 362 & 0.4 \\
\hline 33 & $\mathbf{R} \mathbf{I}$ & 15 & & 2020 & 1.00 & $1,207,367$ & 345 & 0.4 \\
\hline 34 & DC & 11 & 0.4 & 2022 & 0.86 & $1,114,100$ & 254 & 0.5 \\
\hline 35 & IA * & 0 & & 2020 & 1.00 & 367,920 & 105 & $\begin{array}{c}0.4 \\
9.2 \%\end{array}$ \\
\hline
\end{tabular}

According to AEO 2008 total electricity sales in 2020 will be 4,261 TWHrs, with 120 GWs of new generation capacity expected between 2007 and 2020. The table shows that current state RPS requirements will result in 393 TWHrs, or $\sim 9.2 \%$ of electricity sales in 2020.

Federally, the House passed a broad energy bill in 2007 (H.R. 3221) that would set a standard of $15 \%$ of sales by 2020 . A similar provision in another energy bill (H.R. 6) failed in the Senate. Various alternatives have been promoted but none collected sufficient support to pass. More recently, the House passed a non-binding resolution (H. Con. Res. 25) on 10/15/07 that $25 \%$ of all energy, including transportation fuels, should be from renewable energy by 2025 . 
An RPS in essence carves out some portion of the electricity market into a premium sub-market where only renewable energy technologies compete. It both mandates the development of the sub-market as a whole but allows competition within it to encourage the advance the different technologies and lower the overall cost. The amount of the extra cost can be set by the penalty that must be paid if utilities do not meet the target percentage or a cap on the price of RECs. If REC costs are too high then it will be cheaper for the utility to pay the penalty or to pay the cap instead of buying the RECs.

One difficulty is deciding what technologies qualify as renewable. Different states and interests have pursued a broader or narrower set. Examples of disputed technologies are waste coal, municipal solid waste, large hydroelectric and cogeneration. Technically, hydroelectric power is renewable, while fossil-fired cogeneration is not, but some states preclude the former and include the latter. All include wind, solar, geothermal and biomass.

Recently the DOE issued a report on the feasibility of expanding wind to $20 \%$ of domestic electricity needs by 2030 (EERE 2008). This is significantly higher than the $\sim 11 \%$ expected from existing state RPS goals. The report determined that a large amount of wind capacity could be built and transmission lines used to transmit the power to other parts of the country. The map below (Figure 2) shows the possible transmission line expansion that would be needed to distributed the abundant wind energy to load centers and to states with less renewable options. For example, if there were a federal RPS requiring that renewable energy be brought into the Southeast this would most likely be wind from Texas and the Midwest.

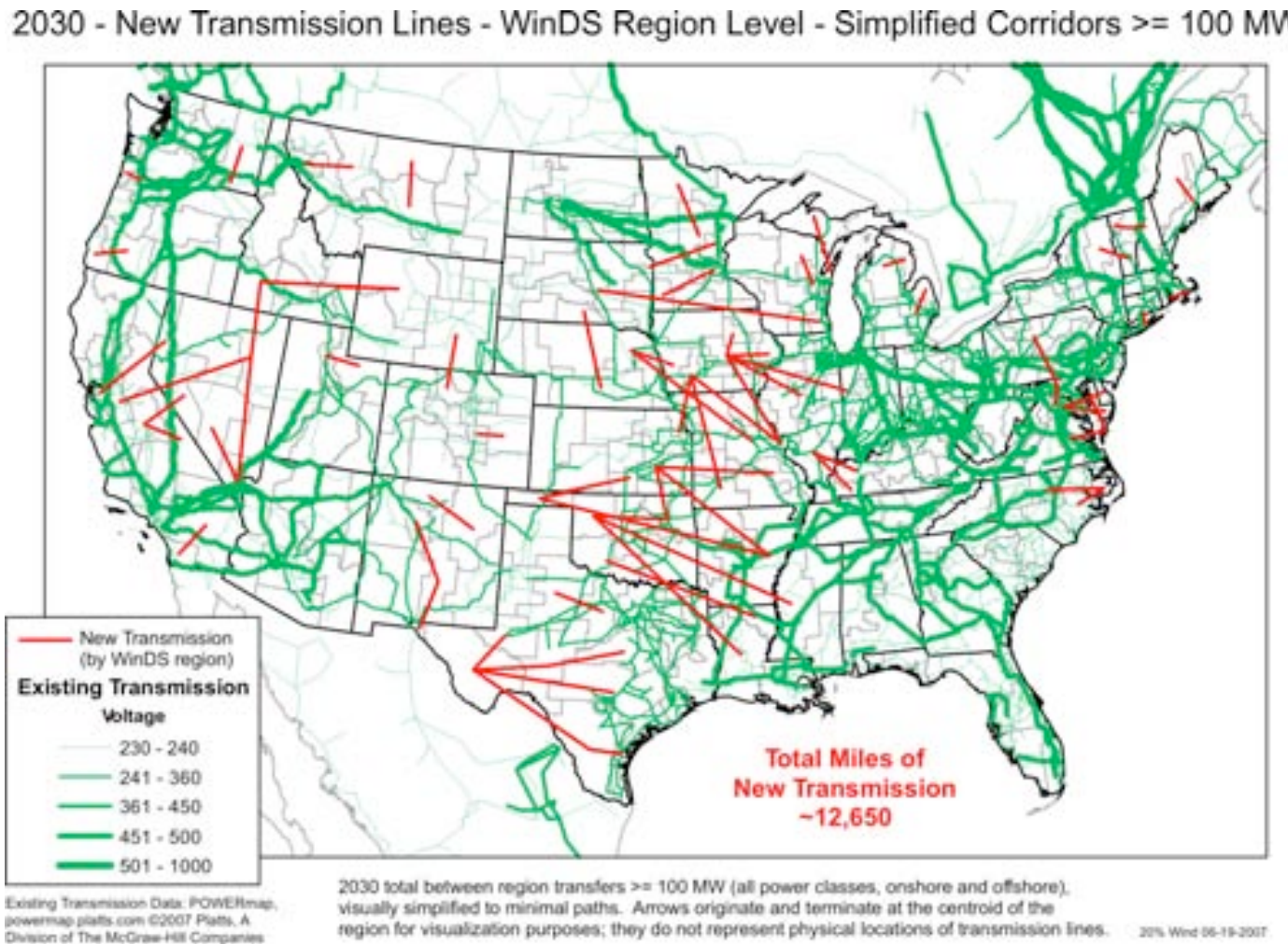

Figure 2. New transmission lines required under $20 \%$ Wind by 2030 scenario (EERE 2008) 


\section{Regional Renewable Deployment Estimates}

Renewable energy has a wealth of definitions. For the most part, in this paper, we will use the definition from the Sen. Jeff Bingaman proposed amendment (Bingaman ARP07513) to the Public Utility Regulatory Policy Act of 1978. It excludes existing hydroelectric power and generation from municipal solid waste as a renewable resource. However, these two technologies are also excluded from both the numerator and denominator of the calculation. Aside from overall AEO electric generation number, Figure 4, the analysis in this paper will not include conventional hydro or municipal waste in the generation calculations.

The regions used for this analysis (Figure 3) are those defined in the Energy Information Administration NEMS model (EIA 2008). These regions are based on the North American Electric Reliability Council regions from 2004 and have not been adjusted yet to reflect the new region definitions. The EPRI NESSIE model also uses these regions in its analysis of the electric power sector.

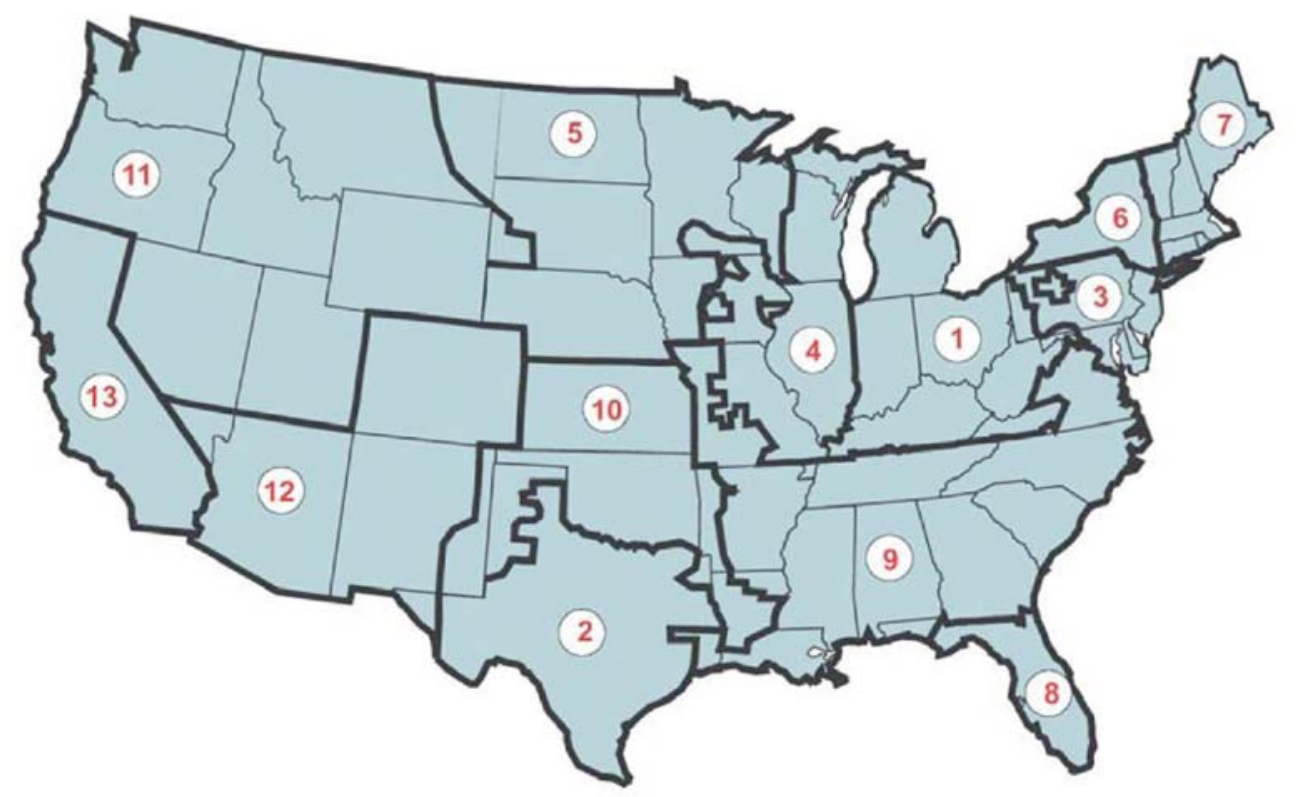

1. ECAR—East Central Area Reliability Coordination Agreement

2. ERCOT - Electric Reliability Council of Texas

3. MAAC - Mid-Atlantic Area Council

4. MAIN - Mid-America Interconnected Network

5. MAPP_Mid-Continent Area Power Pool

6. NPCC $-\mathrm{NY}$ - Northeast Power Coordinating Council / NY

7. NPCC -NE - Northeast Power Coordinating Council / New England

8. FRCC — Florida Reliability Coordinating Council;

9. SERC — Southeastern Electric Reliability Council

10. SPP - Southwest Power Pool

11. WECC-NW - Western Electricity Coordinating Council / Northwest Power Pool Area

12. WECC-RMPIANM - Western Electricity Coordinating Council / Rocky Mountain

Power Area and Arizona-New Mexico-Southern Nevada Power Area

13. WECC-CA - Western Electricity Coordinating Council / California

Figure 3. Regions used by EIA NEMS and EPRI NESSIE 


\subsection{NEMS AEO2008 Reference Case 2008}

Table 2 shows the amount of generation by each technology in AEO2008 for the reference case estimated generation in 2008. The total generation is $4,165 \mathrm{TWh}$ with coal at $48 \%$, gas $21 \%$, nuclear $19 \%$ and renewable at $3 \%$.

Table 2. 2008 Generation by technology in the AEO2008 Reference Case (TWh)

\begin{tabular}{|c|c|c|c|c|c|c|c|c|c|c|c|c|c|}
\hline & ECAR & ERCOT & MAAC & MAIN & MAPP & $\begin{array}{l}\text { NPCC/ } \\
\text { NY }\end{array}$ & $\begin{array}{l}\text { NPCC/ } \\
\text { NE }\end{array}$ & FRCC & SERC & SPP & $\begin{array}{l}\text { WECC/ } \\
\text { NWP }\end{array}$ & $\begin{array}{l}\text { WECC/ } \\
\text { RMA }\end{array}$ & $\begin{array}{l}\text { WECC/ } \\
\text { CA }\end{array}$ \\
\hline Coal & 514.5 & 112.2 & 133.8 & 181.9 & 124.3 & 18.5 & 19.9 & 72.6 & 466.2 & 139.9 & 79.4 & 123.0 & 27.8 \\
\hline Oil & 3.3 & 1.0 & 3.6 & 1.8 & 0.9 & 8.8 & 3.3 & 13.1 & 7.2 & 1.2 & 0.3 & 0.5 & 0.6 \\
\hline Gas & 38.9 & 171.5 & 35.4 & 28.8 & 2.3 & 52.3 & 60.0 & 76.5 & 177.5 & 41.3 & 32.7 & 9.3 & 84.3 \\
\hline Nuclear & 61.1 & 38.7 & 108.0 & 117.0 & 23.9 & 46.4 & 30.3 & 30.3 & 260.3 & 9.3 & 8.9 & 2.4 & 43.0 \\
\hline Pump Stor & 3.1 & 2.9 & 1.9 & 0.4 & 0.4 & 0.4 & 1.0 & 3.2 & 1.1 & 1.0 & 0.2 & -0.1 & 2.1 \\
\hline Hydropower & 3.2 & 0.7 & 4.5 & 3.1 & 11.4 & 24.2 & 6.8 & 0.1 & 35.5 & 5.9 & 126.3 & 13.4 & 34.6 \\
\hline Geothermal & 0.0 & 0.0 & 0.0 & 0.0 & 0.0 & 0.0 & 0.0 & 0.0 & 0.0 & 0.0 & 2.5 & 1.1 & 13.0 \\
\hline Muni Waste & 1.0 & 0.6 & 3.4 & 1.4 & 0.6 & 1.4 & 2.6 & 2.0 & 1.4 & 0.0 & 0.7 & 0.1 & 2.2 \\
\hline Biomass & 2.7 & 0.1 & 1.0 & 1.1 & 2.3 & 0.5 & 3.7 & 2.1 & 18.5 & 2.5 & 3.2 & 0.3 & 3.3 \\
\hline Solar Ther & 0.0 & 0.0 & 0.0 & 0.0 & 0.0 & 0.0 & 0.0 & 0.0 & 0.0 & 0.0 & 0.0 & 0.4 & 0.7 \\
\hline Solar PV & 0.0 & 0.0 & 0.0 & 0.0 & 0.0 & 0.0 & 0.0 & 0.0 & 0.0 & 0.0 & 0.0 & 0.1 & 0.8 \\
\hline Wind & 1.3 & 11.5 & 0.7 & 3.2 & 7.8 & 1.7 & 0.3 & 0.0 & 0.2 & 4.3 & 9.4 & 3.6 & 5.9 \\
\hline total & 629.0 & 339.2 & 292.4 & 338.7 & 174.0 & 154.2 & 128.1 & 200.0 & 967.8 & 205.5 & 263.7 & 254.2 & 218.3 \\
\hline$\%$ total & $15.1 \%$ & $8.1 \%$ & $7.0 \%$ & $8.1 \%$ & $4.2 \%$ & $3.7 \%$ & $3.1 \%$ & $4.8 \%$ & $23.2 \%$ & $4.9 \%$ & $6.3 \%$ & $6.1 \%$ & $5.2 \%$ \\
\hline
\end{tabular}

From these figures the percentages of renewable generation (with and without hydro and municipal waste) are calculated by region. Figure 4 shows the percentage of generation in 2008 by region if hydro and municipal solid waste generation are classified as renewable.

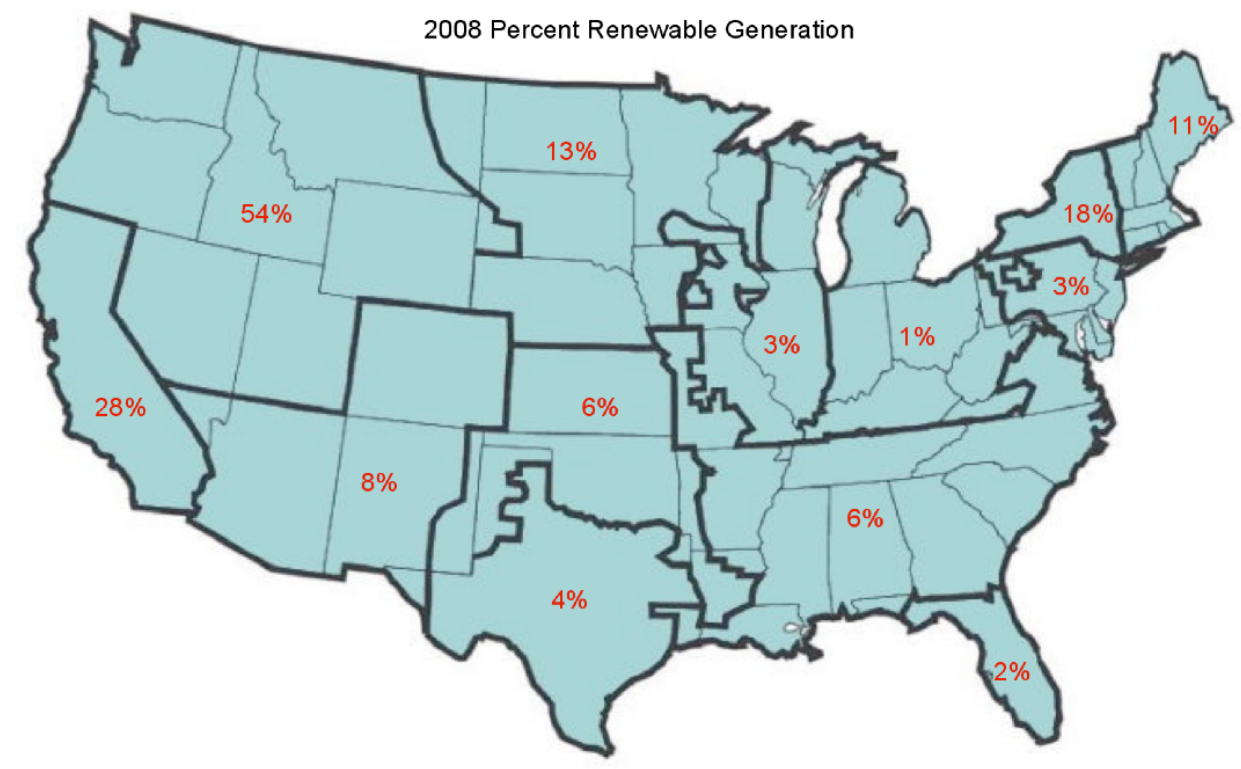

Figure 4. Renewable energy generation as a percentage of total generation in 2008 
Figure 5 shows the percentages if hydro and municipal waste generation are not considered as renewable or in the total for calculating the renewable percentages. The largest drops in percentage are in the Pacific Northwest, New York, and California, since hydro power is a large part of their generation mix.

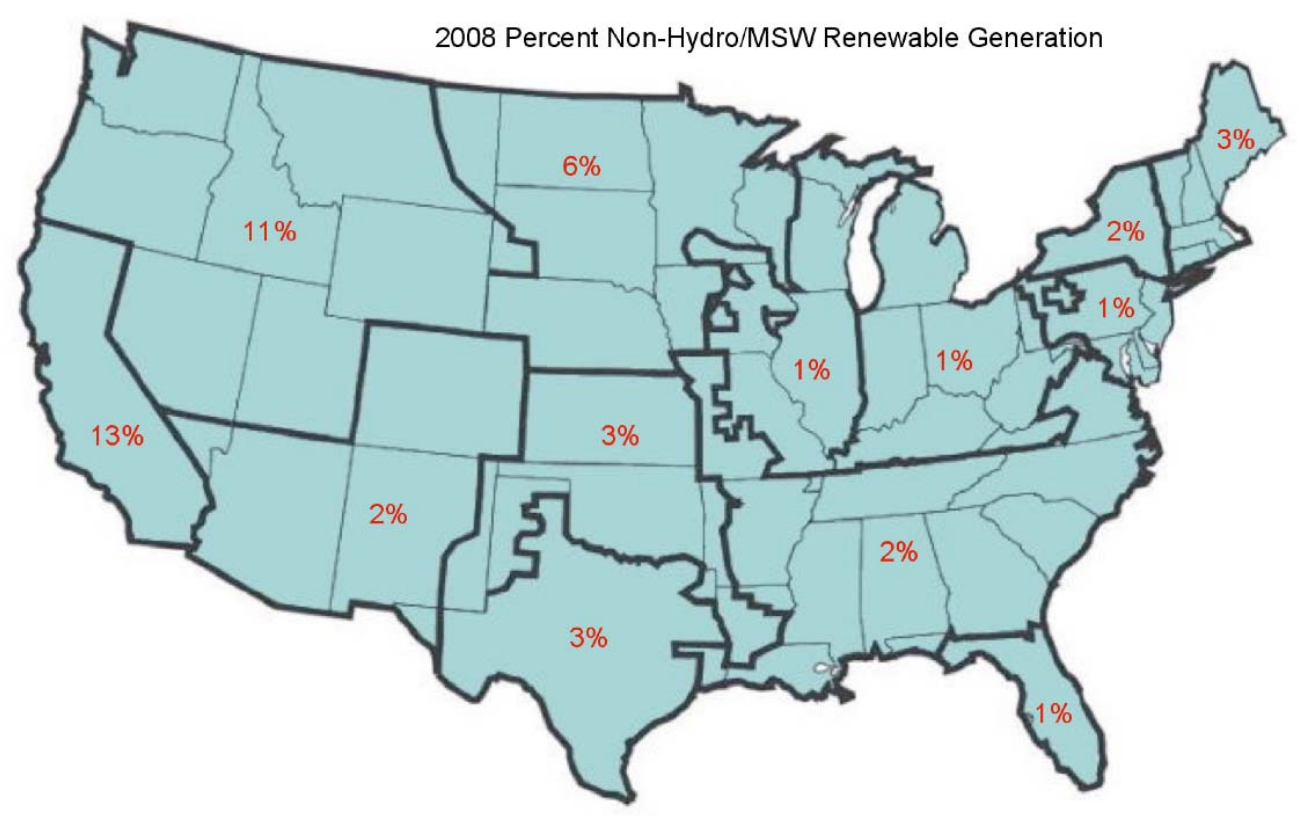

Figure 5. $2008 \%$ Renewable generation not including hydro or municipal waste

Even though there are regions with relatively high percentages, those regions with the largest amounts of generation generally have the lowest relative percentages of renewables. Over all, the AEO estimate for renewable generation in 2008 is $2.8 \%$, based on 110 of renewable generation out of $3878 \mathrm{TWh}$ total generation, with MSW and conventional hydropower removed.

Table 3 shows for each region the total TWh of generation, that generation by percentage of the national total, and the percentages of renewables, as shown in the figures above.

Table 3. 2008 Regional generation (by amount and \%) and renewable \% of generation

\begin{tabular}{|c|c|c|c|c|c|c|c|c|c|c|c|c|c|}
\hline & ECAR & ERCOT & MAAC & MAIN & MAPP & $\begin{array}{l}\text { NPCC/ } \\
\text { NY }\end{array}$ & $\begin{array}{l}\text { NPCC/ } \\
\mathrm{NE}\end{array}$ & FRCC & SERC & SPP & $\begin{array}{l}\text { WECC/ } \\
\text { NWP }\end{array}$ & $\begin{array}{l}\text { WECC/ } \\
\text { RMA }\end{array}$ & $\begin{array}{l}\text { / WECC/ } \\
\text { CA }\end{array}$ \\
\hline Total TWh & 629 & 339 & 292 & 339 & 174 & 154 & 128 & 200 & 968 & 206 & 264 & 254 & 218 \\
\hline$\%$ National & $15 \%$ & $8 \%$ & $7 \%$ & $8 \%$ & $4 \%$ & $4 \%$ & $3 \%$ & $5 \%$ & $23 \%$ & $5 \%$ & $6 \%$ & $6 \%$ & $5 \%$ \\
\hline$\%$ Renew & $1 \%$ & $4 \%$ & $3 \%$ & $3 \%$ & $13 \%$ & $18 \%$ & $11 \%$ & $2 \%$ & $6 \%$ & $6 \%$ & $54 \%$ & $8 \%$ & $28 \%$ \\
\hline $\begin{array}{l}\text { \% Non- } \\
\text { Hydro/MSW } \\
\text { Renew }\end{array}$ & $1 \%$ & $3 \%$ & $1 \%$ & $1 \%$ & $6 \%$ & $2 \%$ & $3 \%$ & $1 \%$ & $2 \%$ & $3 \%$ & $11 \%$ & $2 \%$ & $13 \%$ \\
\hline
\end{tabular}

\subsection{NEMS AEO2008 Reference Case for 2020}

The Annual Energy Outlook for 2008 includes a number of different scenarios of the future. The most frequently used is the Reference case, which uses EIA's estimate of expected costs, supplies, and demands for energy through 2030. It does not include any policy changes from 
those currently in place. Although this represents an unrealistic, static future, it does provide a baseline from which to compare alternative policies and the effect of those polices on the electric sector.

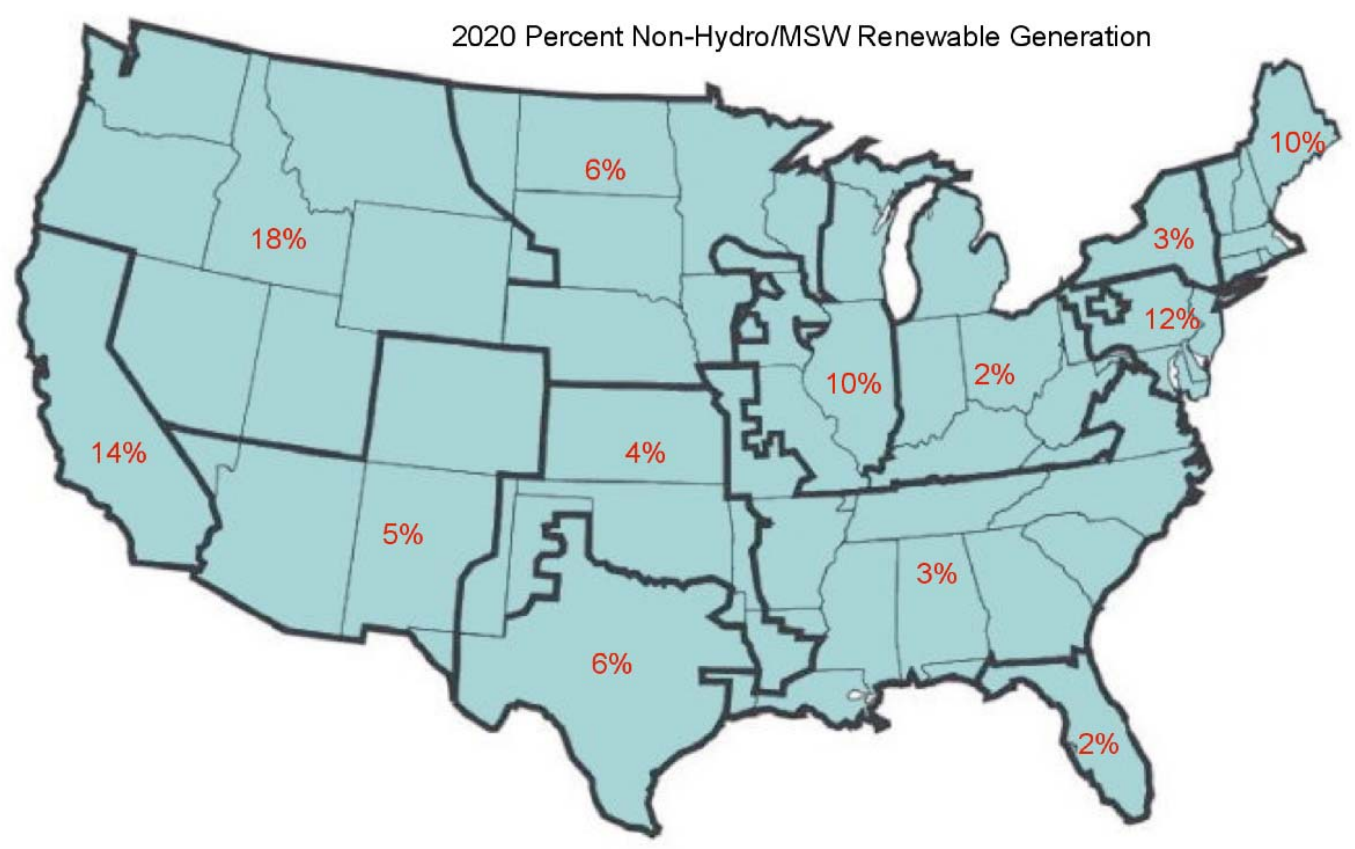

Figure 6. $2020 \%$ Renewable generation not including hydro or municipal waste

\subsection{Requirements to meet a Federal RPS}

If a Federal RPS requires $15 \%$ of renewables by 2020 , then using the renewables expected to be deployed in the region under the NEMS Reference Case will show both excesses and shortfalls. The estimated percentages for each region are shown in Figure 6 above. Comparing these deployment numbers to $15 \%$ of electricity sales gives an idea of the amount of new renewable energy generation that needs to either occur in the region, or be imported from other regions.

Figure 7 shows the amount of generation needed in terms of GW-years. That is the amount of generation a power plant would generate if operated at full power for the full year. If the power plants only operate for a fraction of the year, then more capacity is needed. For example, typical wind plants may only have a capacity factor of $33 \%$, meaning they produce one third of the power that they could if they operated at full power continuously. All power plants have a capacity factor of less than 1 .

As can be seen NEMS predicts a significant energy short fall in SERC and ECAR and there is not an excess of renewable energy in any regions except the NW. This implies that Renewable Energy Credits (RECs) would see a value if there was a 15\% Federal RPS. The REC value would also depend on other polices such as a carbon cap or continued changes in State RPS. 


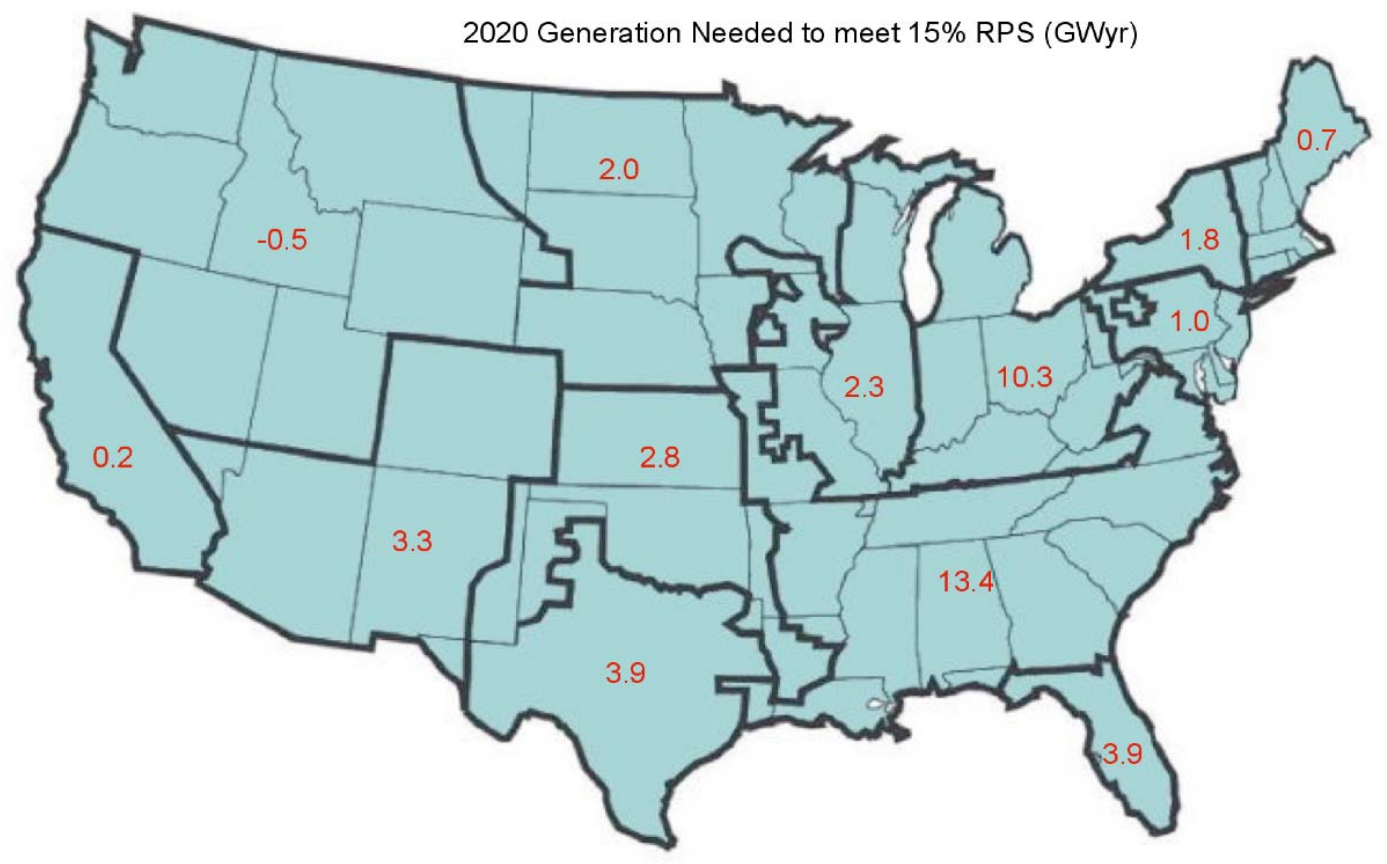

Figure 7. Additional generation needed in each region to meet a 15\% RPS in 2020

Figure 8 shows the amount of capacity needed if renewable plants operated on average $33 \%$ of the time. This same capacity would be required in other regions if the renewable generation is to be imported.

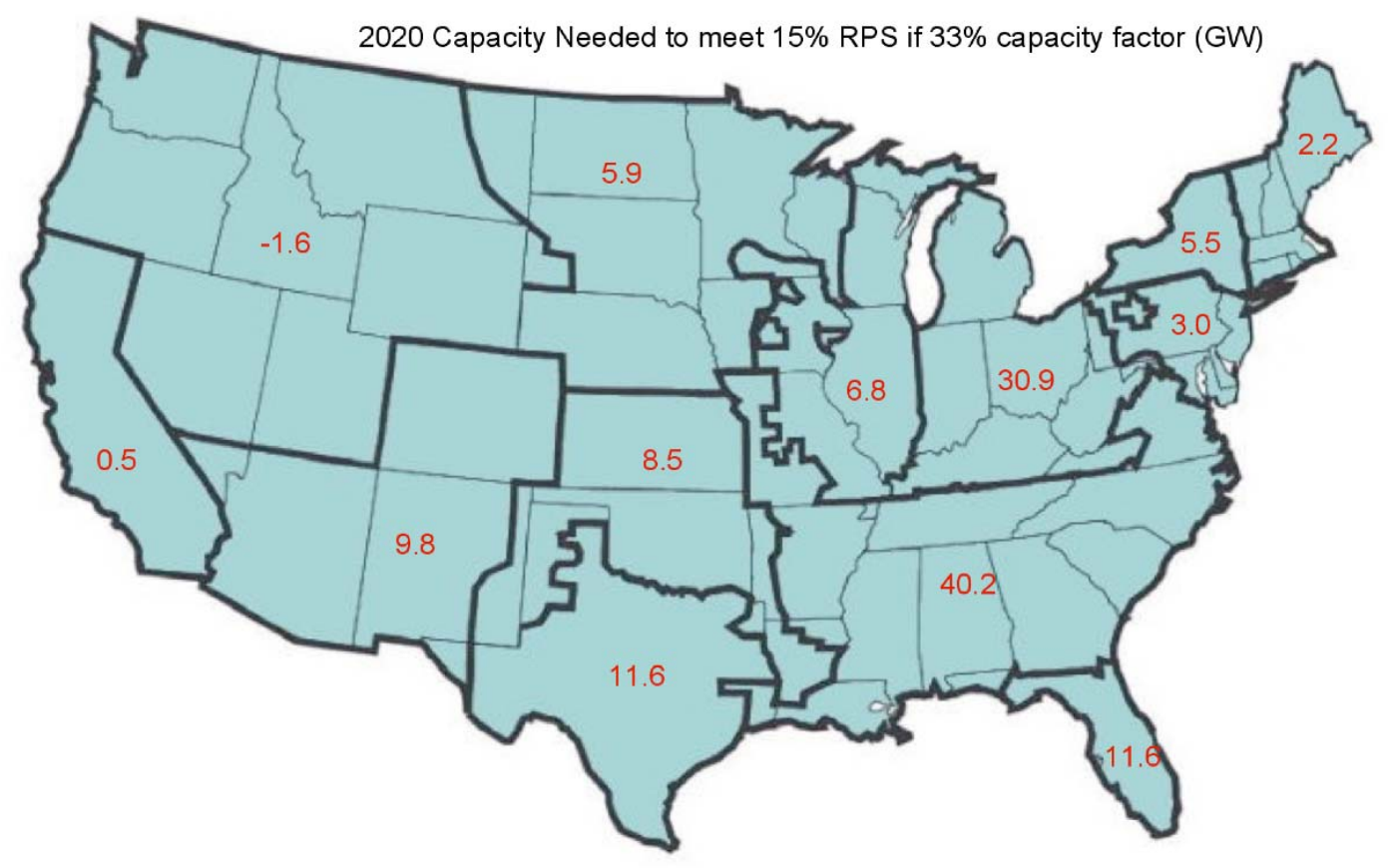

Figure 8. Additional capacity needed to meet $15 \%$ RSP with a $33 \%$ capacity factor 


\subsection{NESSIE Electric Power Sector Model}

A major challenge to forecasting deployment of renewable and other electric generation options is to develop an energy system model that is not only valid but also flexible and easy to use. These attributes make it possible for multiple users to effectively apply the model for sensitivity and scenario analyses without necessarily being expert on the model's internal details. As characterized below, EPRI's National Electric System Simulation Integrated Evaluator (NESSIE) was developed to capture complexities without sacrificing flexibility.

NESSIE was originally developed as a capacity expansion and operations model for the U.S. electric sector. It is designed to study the sustainability of the electric system, understand the role of new, low- and non-emitting generation technologies, and analyze the profitability of existing and new generating assets under varying scenarios for the future. ${ }^{1}$ NESSIE incorporates submodels to simulate bulk power markets in individual U.S. regions and to calculate prices and quantities at both regional and aggregate levels. The prices and quantities, along with the values for other parameters employed as inputs to NESSIE, provide the basis for calculating cash flows and profits for generating technologies in regional electricity markets.

NESSIE requires many input values. In general, the inputs fall into two categories. The first category covers the characteristics of generating technologies, such as fixed and variable costs, efficiency, availability, capacity factor, etc. These cost-performance characteristics and projections are generally based on historic data and expert judgments.

The second category of inputs includes values determined in markets that are separate from or broader than regional electricity markets. These markets include, for example, natural gas markets (in which electricity generation is only one of many competing uses for gas) and other fuel markets, broader energy markets (in which electricity is one form of energy that competes with others to deliver services), and emission allowance markets (which, while closely related to electricity markets, are separate and extend over larger geographic regions).

Providing these market value inputs requires the use of the National Energy Modeling System (NEMS) so that all energy sectors are considered. NESSIE employs NEMS for a variety of reasons:

- NEMS is comprehensive making it suitable for modeling a wide range of scenarios reflecting different regulatory and other conditions.

- NEMS is viewed as credible within the modeling community, given its association with EIA and its long history of use for analyzing the U.S. energy system.

- NEMS is publicly available from and extensively documented by EIA, characteristics that have led to it being fairly widely used and well understood, relative to other large and complex energy system models.

Figure 9 illustrates the ways in which the two models are used together, and it identifies key inputs and outputs from each of the models.

\footnotetext{
${ }^{1}$ EPRI, 2003. Evaluating the Potential Effects of Environmental Regulation and Other Variables on Future NonEmitting Generation Profitability. Palo Alto, CA: 1007732.
} 


\section{EIA National Energy Modeling System}

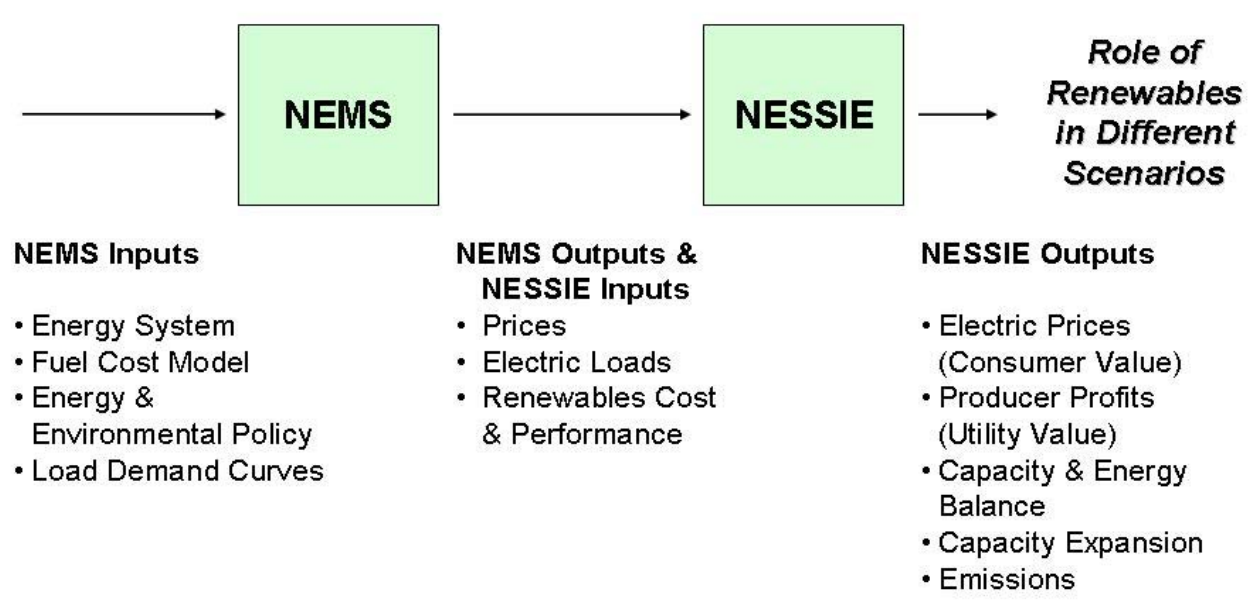

\section{EPRI National Electric System Simulation Integrated Evaluator}

- Emissions

\section{Figure 9. Relations Between NEMS and NESSIE (Source: EPRI)}

It is an important point that NEMS is a general equilibrium model where supply and demand are specified as functions. Thus, both supply and demand change as the model solves for equilibrium. The equilibrium is reached by finding the demand that is consistent with the prices generated by the supply function. If a scenario leads to higher costs for electricity, then the demand for electricity will drop. NESSIE follows the same equilibrium approach for the electric sector, starting with results from NEMS as an input.

In January 2007, a comparison of NEMS, NESSIE, and NREL's WinDS (now called REeds) models was completed to determine how renewable generation is treated in each model. The results show that all three of these energy models have advantages and disadvantages. ${ }^{2}$ A key conclusion for the NESSIE model was to expand the number of renewable options and the details on treatment of regional resource availability and uncertainty regarding technology evolution.

There are a number of generation options for meeting electrical demand. Therefore deployment of renewable generation depends on the relative cost of all other generation options as well as factors such as demand growth and implementation of conservation or energy efficiency measures. The NESSIE model covers the following generation options:

- Thermal Generation: conventional and advanced coal, including near-term integrated gasification combined cycle (IGCC) and longer-term technology with carbon capture and storage (CCS); old and new natural gas combined cycle; old and new gas turbine; oil/gas boiler; nuclear and advanced nuclear; biomass; landfill gas; municipal solid waste; geothermal; fuel cells; and biomass cofiring in old and new coal units.

- Nonthermal Generation: wind; solar, including central-station solar thermal electric and photovoltaic (PV); and hydro, including conventional (impounded), run of river and pumped storage.

\footnotetext{
${ }^{2}$ EPRI, 2007. Role of Renewable Energy in a Sustainable Electricity Generation Portfolio. Palo Alto, CA: 1012730.
} 
Regional demand is based on the NEMS model estimates, but can be adjusted by region for different growth scenarios or energy efficiency measures.

\subsection{NESSIE National and Regional Results}

In order to look at compare expected renewable deployment with and without the Federal RPS a base case was run assuming 15\% renewable required in 2020 and $20 \%$ in 2030. The assumption for this are were as follows:

- Natural gas varies from $\$ 4.70$ to $\$ 8.10 / \mathrm{MMBtu}$ by 2030 and varies by season/region (high/low gas scenarios)

- Incentives include production and investment tax credits and a $\$ 9 / \mathrm{MW}$ - hour proxy for the state RPSs

- Emission allowances, slow application of $\mathrm{CO} 2$

- $\$ 7 /$ ton in 2015 to $\$ 24 /$ ton in 2030

- SOX @ \$244-487/ton, increasing at 4\%/year

- Nox@ \$2005-2435/ton increasing at 4\%/year

- HG@ @19,119/lb increasing at 9\%/year

- Demand growth is $\sim 1.4 \%$ /year

All the generation technology options are expected to improve over time, however, emerging technologies such as solar or advanced nuclear have more room for improvement while mature technologies conventional hydro or coal are not considered options. Older technologies such oil boiler or pulverized (old) coal are retired. Some generation technologies have deployment limits on how much, and how soon, deployment can occur such as nuclear or IGCC. Also renewables are limited by the estimated available regional resources, which are estimated in the model based on NREL and other data bases.

The model calculates all parameter relate to electrical generation and dispatch including the mix, fuel usage, emissions, reserve requirements, base, shoulder, peak and un-served demand, etc. Operation of any particular power plant depends on heat rate, fuel and operating costs. Capacity expansion depends on the cost of the technology as well as the fit into for meeting dispatch requirements. Five-year increments are used, up to 2050. For example Figure 10 shows the expected US generation mix and Figure 11 shows the expected capacity additions in the base case using a 1.4\% load growth. Note this growth is higher than used in the most recent EIA base case, which was $\sim 0.9 \%$. 


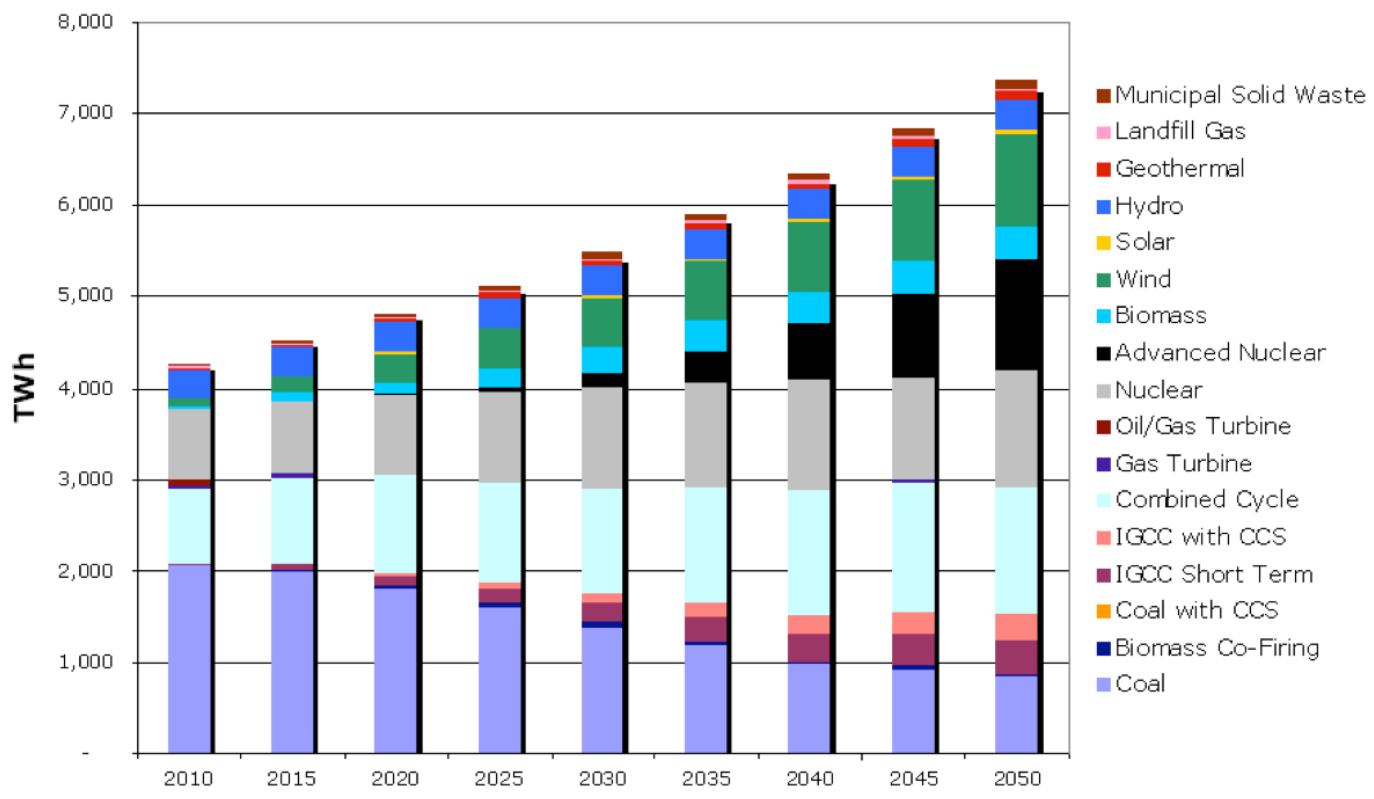

Figure 10. Base Case US Electricity Generation (1.4\% growth)

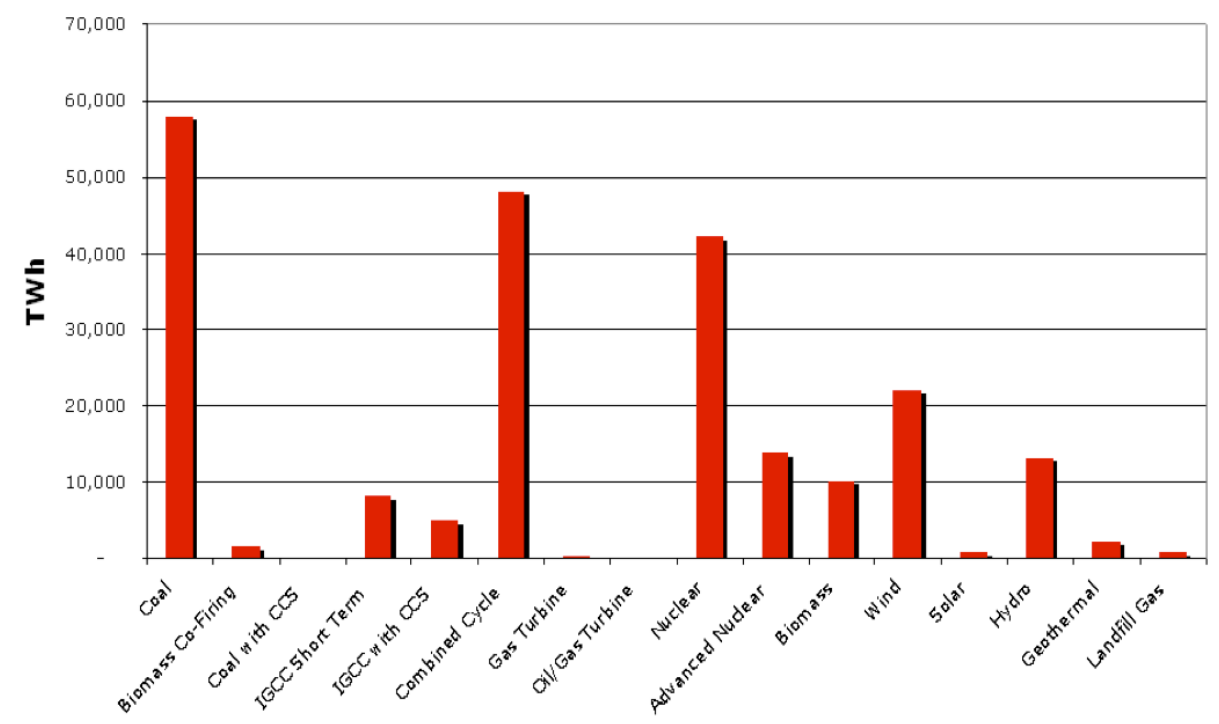

Figure 11. Base Case Capacity Additions Each 5-year Period

Renewable deploy based on their relative cost including incentives and tax credits and considering capacity factors as well as capacity credits. Figure 12 show the expected deployment as a percent of total electrical generation. 


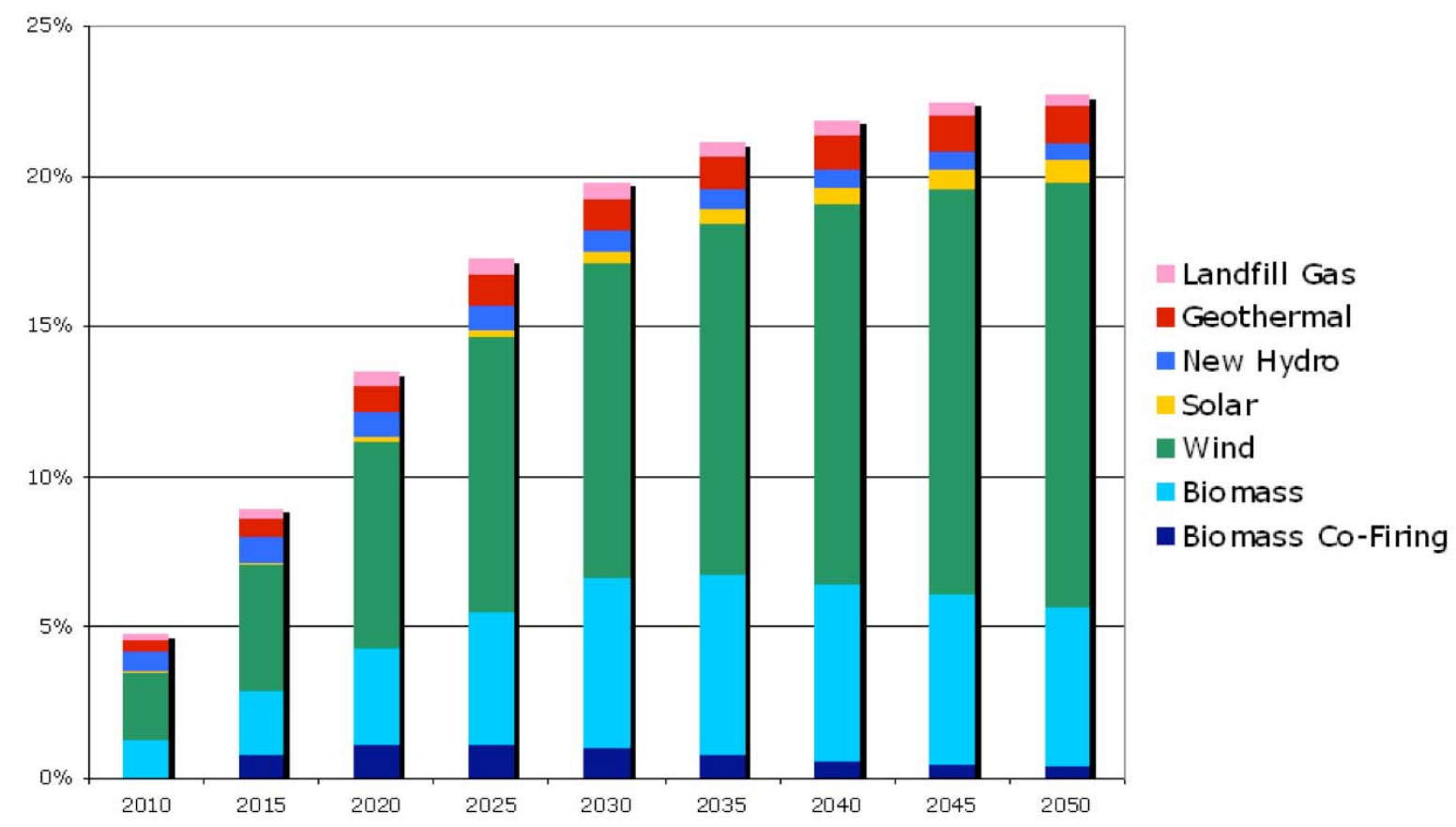

Figure 12. Base Case Generation by Renewable Energy as Percent of Total Generation

Clearly there are many factors that will affect renewable deployment into the electric grid. From previous discussions it can be argued that under nearly all possible scenarios, the Southeast US would be short of a $15 \%$ renewable goal in 2020 or a $20 \%$ goal in 2030 .

Figure 13 shows that this is the case when applying EPRI's NESSIE electric sector model. It provides an estimate of excesses and shortage of renewable generation by region based on a $20 \%$ RPS in 2030. Both SERC/STV and FL fall significantly short of a $15 \%$ goal, let alone a $20 \%$ by 2030. (In NESSIE, SERC/FL is what NEMS labels FRCC and SERC/STV is SERC in NEMS.) However the NESSIE model result has almost twice the renewable deployment of AEO 2008. Reasons include differences in generation technology advancements, consideration of State RPSs, and expectation of a federal $\mathrm{CO}_{2}$ policy, beginning by 2015. Another important difference is the anticipated renewable deployment in ERCOT, SPP and MAPP, which are above the National RPS. This excess deployment is mostly wind energy and would make it possible to either ship renewable energy into the SE or to sell RECs to make up the short fall. 


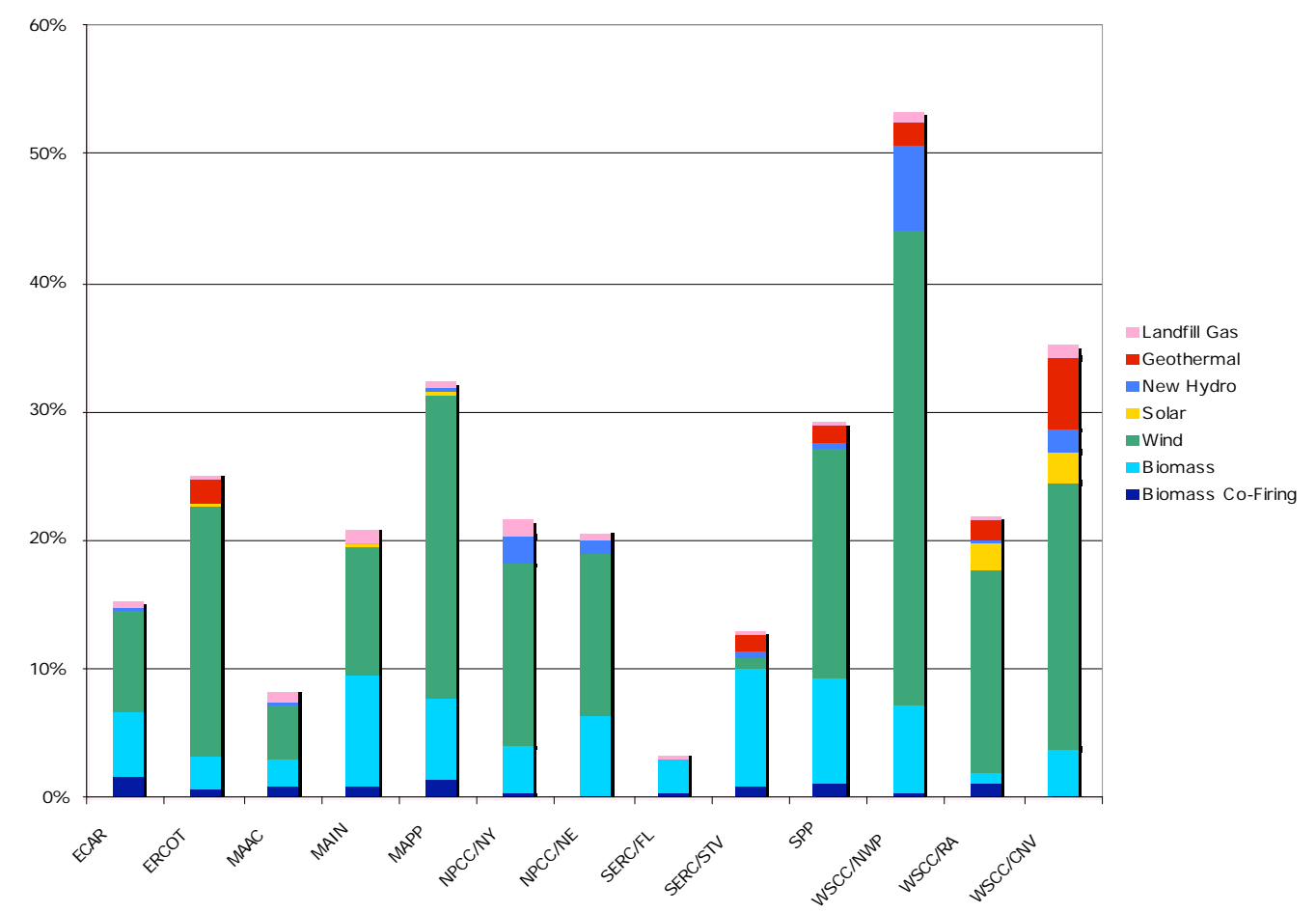

Figure 13. Regional Renewable Generation as \% of Total Generation 2030 


\section{Inter-Regional Transmission and Renewable Generation}

Many regions currently trade a significant amount of electricity across their boundaries. In addition, power producers in one region can own plants in a neighboring region and use a dedicated amount of the transmission grid to bring that power to marker. The limits on the amount of transmission are a function of the number of lines, the voltage rating of the lines, available capacity, and the distance that the power needs to travel. For short lines, the limits are based on thermal loads that the lines can handle before excessive sagging. For longer distances, impedance and other electrical parameters can lower the limits of power transfer.

A recent study by American Electric Power (AEP 2008) stated that:

To assess the load carrying ability, or loadability of a high voltage transmission line, the concept of Surge Impedance Loading (SIL) is commonly used. ${ }^{l}$ SIL is a convenient yardstick for measuring relative loadabilities of transmission lines operating at different voltages, and is that loading level at which the line attains reactive power self-sufficiency. For example, an uncompensated $765 \mathrm{kV}$ line has a SIL of approximately $2400 \mathrm{MW}$. By contrast, a typical $500 \mathrm{kV}$ line of the same length has a SIL of approximately $910 \mathrm{MW}$ and a $345 \mathrm{kV}$ line approximately 390 $M W$. The relative loadabilities of $765 \mathrm{kV}, 500 \mathrm{kV}$, and $345 \mathrm{kV}$ considering 150 miles line length (from the St. Clair Curve), are $3840 \mathrm{MW}, 1460 \mathrm{MW}$, and 620 $M W$, respectively. It is apparent that a $765 \mathrm{kV}$ line, 150 miles in length, can carry substantially more power than a similarly situated $500 \mathrm{kV}$ or $345 \mathrm{kV}$ line. Generally, about six single-circuit (or three double-circuit) $345 \mathrm{kV}$ lines would be required to achieve the load carrying ability of a single $765 \mathrm{kV}$ line. Relative loadabilities of the transmission lines also can be viewed in terms of transmission distances over which a certain amount of power, say $1500 \mathrm{MW}$ can be delivered. For a $765 \mathrm{kV}$ line, this loading represents approximately 0.62 SIL $(1500 / 2400=$ $0.625)$ which, according to the St. Clair Curve, can be transported reliably over a distance of up to 550 miles. By contrast, a $345 \mathrm{kV}$ line carrying the same amount of power can transport reliably only up to 50 miles; this distance would increase to about 110 miles for a double-circuit $345 \mathrm{kV}$ line.

1 "Practical Concepts in Capability and Performance of Transmission Lines," H.P. St. Clair, AIEE Transactions on Power Apparatus and Systems, Vol. 72, Part III, December 1953.

\subsection{Transfer Capabilities from NEMS}

The NEMS model incorporates transmission constraints between regions in its analysis by using input assumptions for inter-regional transmission capacity (by year) and removing the generation owned by utilities in other regions. It further reduces the capacity using a list of inter-regional firm contracts by year. The remainder is then available for economy trades depending on the relative cost of power at given periods in neighboring regions. NEMS assumes available transmission within each region.

Figure 15 below shows the amount of capacity available between regions in 2008 before the firm contract amounts are subtracted. Note, for example that capacity into California from the Rocky Mountain region is much less than in the opposite direction. That is due to the power plants in the Rocky Mountain region owned by utilities in California utilizing some of the transmission 
lines across the border. Other regions also show this type of differentiation, but to a more limited extent.

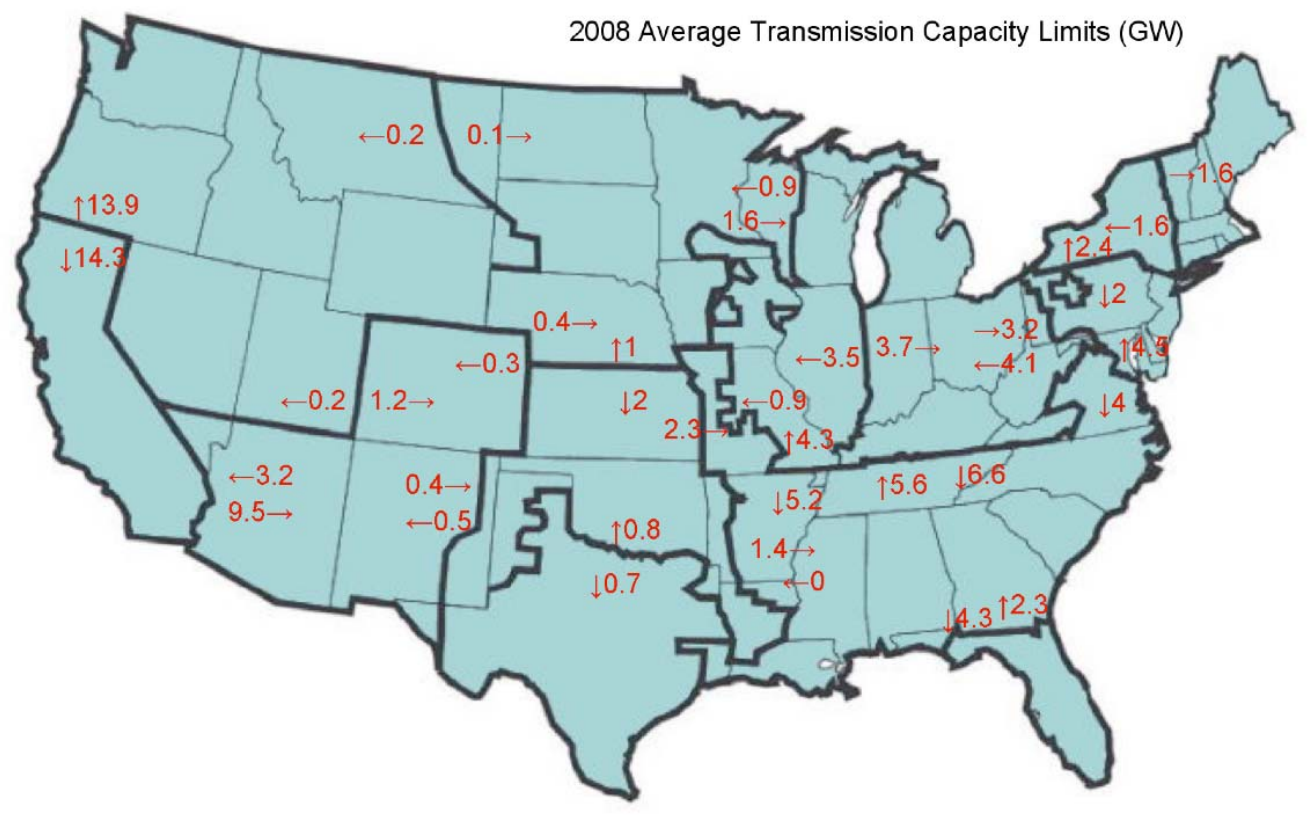

Figure 14. 2008 Inter-Regional Transmission Capacities after planned outside regional generation subtracted

Figure 15 shows the same capacity constraints (before firm contracts) for the NEMS 2020 Reference Case, while Figure 16 shows the amounts after the known firm contracts are removed.

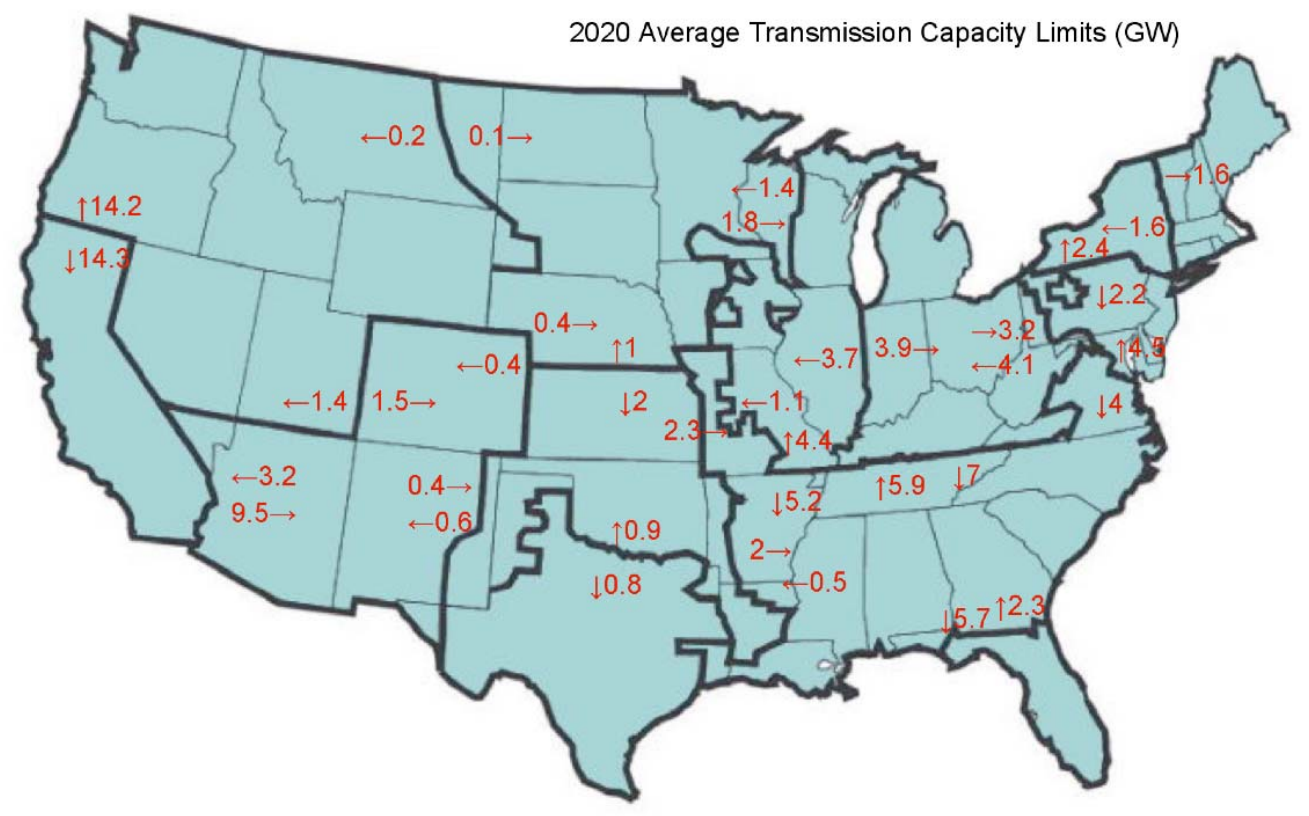

Figure 15. 2020 Planned Inter-Regional Transmission Capacity within NEMS (after planned outside regional generation subtracted) 
Most firm contracts have expired by 2020, so there are only a few regions that show differences between these two 2020 maps

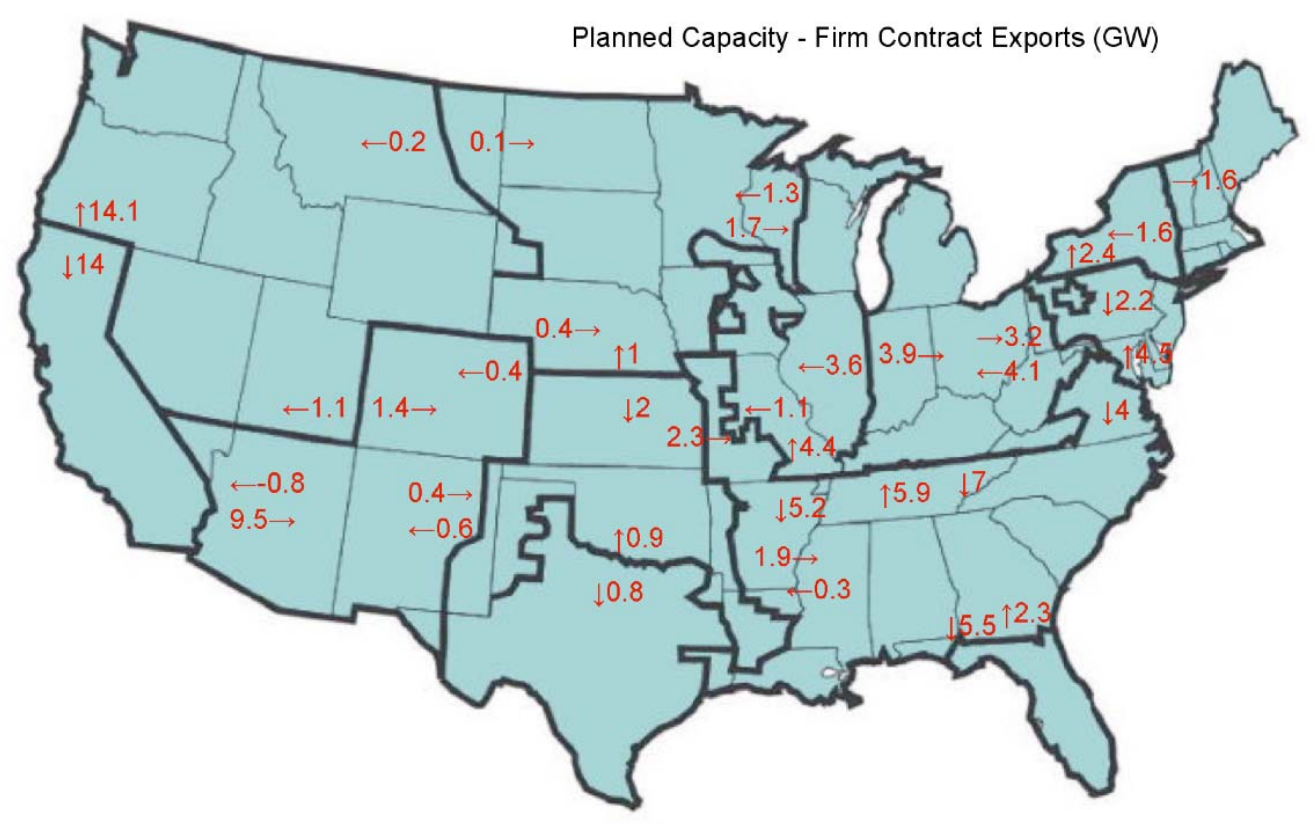

Figure 16. 2020 Planned Transmission Capacity minus outside generation and planned contract trades

\subsection{Current year import/exports from NEMS}

While the figures above show the maximum potential electricity exchange between regions, the NEMS model generally does not utilize all of the potential capacity. Also NEMS does not anticipate new transmission between regions.

Figure 17 shows the amount of electricity imported/exported for each region in 2008. Most of the regions are mainly either an importer or an exporter, but several roughly balance their trades. For example, SERC imported $6.2 \mathrm{GWyr}$ and exported $8 \mathrm{GWyr}$. However, much of the SERC exports were to Florida (5.3 of the $8 \mathrm{GWyr}$ ), so the southeast was a net importer of $6.2 \mathrm{GWyr}$ from the regions where renewable generation may be available, to the north or west.

Using the NEMS assumptions for net import and export capability provides a general idea on the scale of available capacity, but does not address other key factors that would affect transfer of renewable energy. These include availability of transmission within regions to gather and to deliver the renewable energy to market (currently inter region transmission is assumed by both NEMS and NESSIE), time of day, delivery costs, and other regional agreements.

Another key issues is modeling the demand that would lead to the deployment of excess renewable generation in one region with significant renewable resources while backing down on other generation options in the region without good renewable resources. Currently our equilibrium models generally do not include capacity expansion planning for export or input. This issue is discussed in the net section. 


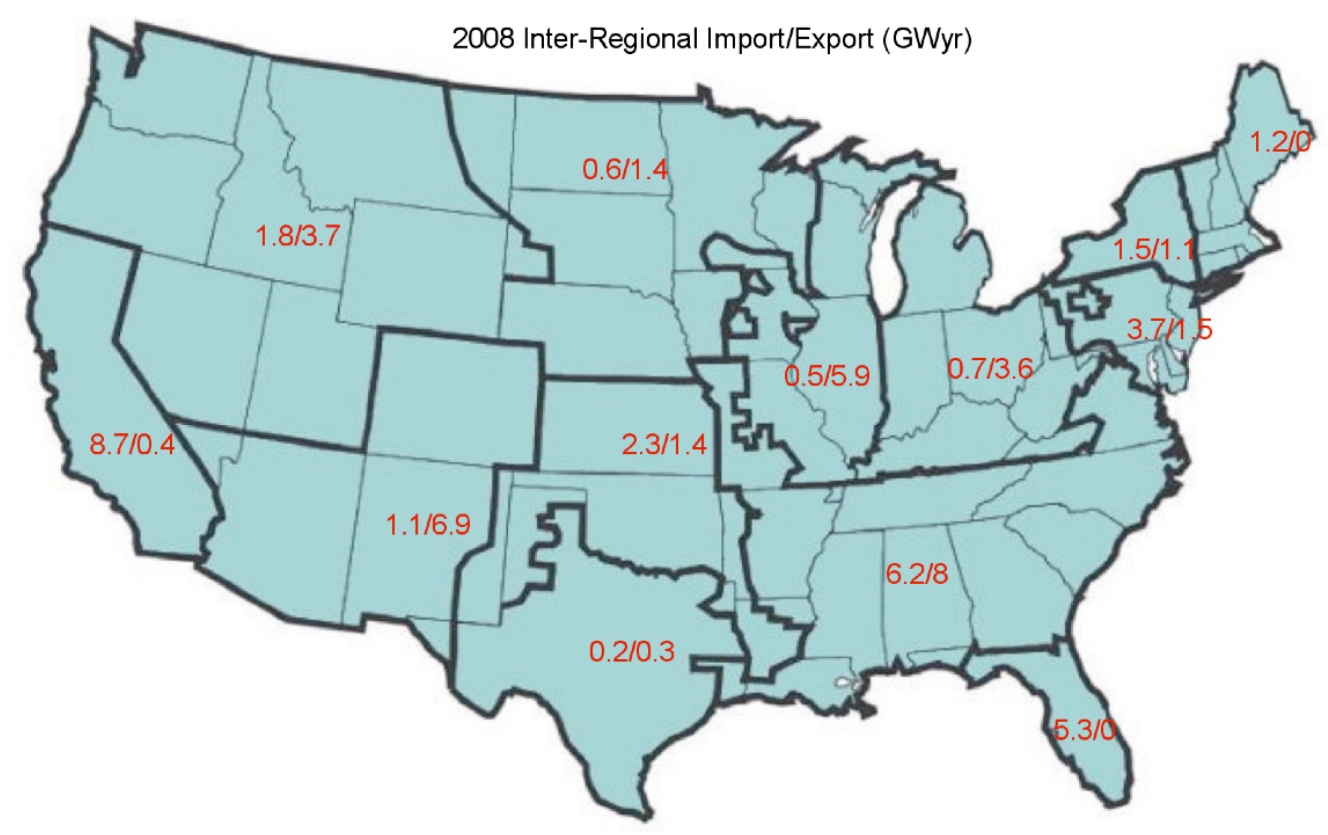

Figure 17. Inter-Regional Imports and Exports in 2008

\subsection{Future Required Transfers to meet an RPS}

Using NEMS or NESSIE model results the expected capacity expansion by region and by generation type can be predicted under different scenarios. This is illustrated in Figure 18 for the NESSIE base case. The deployment of generation in each region considers historical transfers, but is primarily driven by regional demand and the relative economics of the generation options with in the region.

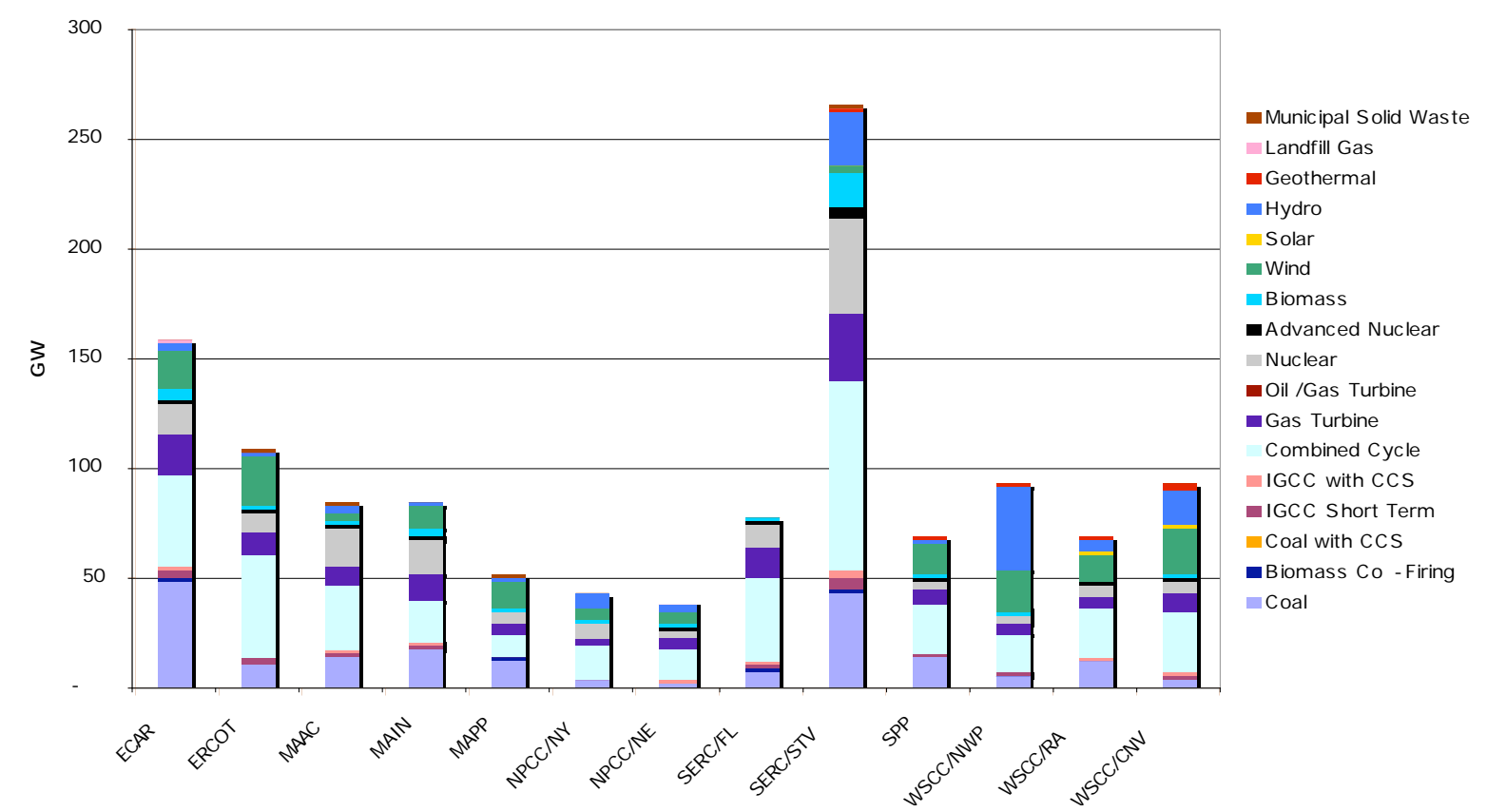

Figure 18. NESSIE Generation Mix and Expected Generation Capacity by Region in 2030 
As can be seen in Figure 18 a very rich wind resource region such as MAPP does not deploy the largest amount of wind generation. Since both NEMS and NESSIE assume inter regional transmission, delivering the wind is not a limiting factor. In each region generation options compete for a share of the demand required. Therefore a renewable technology deployment in any one region depends heavily on the relative economics with other options, including the contribution to peak, shoulder or base load, and on the anticipated demand in that region. Currently the models do not plan for export.

Figure 19 shows the kind of renewable energy transfers that would be required between regions in the case of a mandatory $20 \%$ Federal RPS in 2030. It is based on the expected economic deployment, and dispatch, of renewable generation compared to a $15 \%$ of electricity sales renewable requirement. The scenario uses base case assumptions in the EPRI NESSIE model. For the Southeast (SERC/STV plus SERC/FL) the required renewable energy import is $150 \mathrm{TW}$ hours. In terms of GWyr of renewable capacity it is about $51 \mathrm{GW}$.

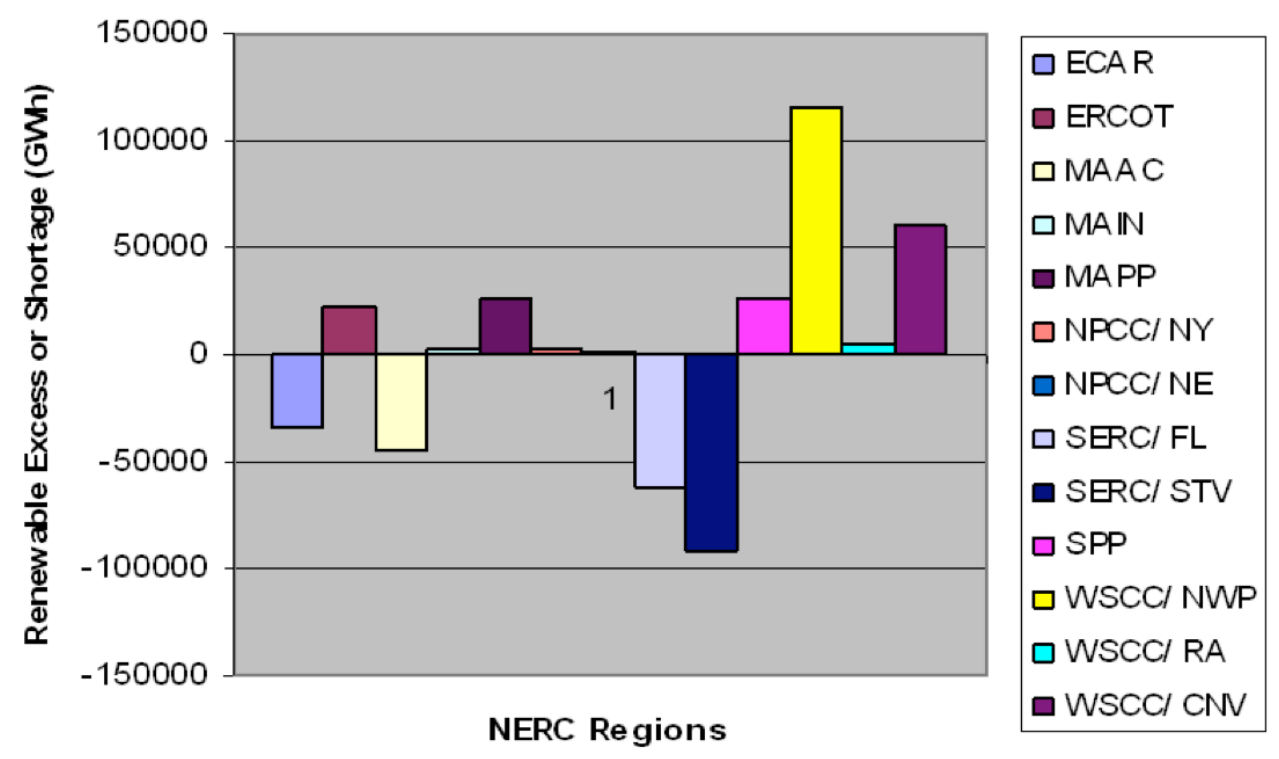

Figure 19. NESSIE result showing needed regional transfers of renewable energy to meet a $20 \%$ RPS in 2030, based on the renewable energy required in each region. 


\section{Potential for Regional Wind Generation}

NREL has developed a wind resource data base. This data base includes the number of square miles of land available in each region at different class of wind speeds from 3 to 7 . Excluded areas that are removed from this total include wet lands, difficult terrain, public parks, cites, etc. Converting these to generating capacity by assuming $5 \mathrm{MW} / \mathrm{km}^{2}$ gives a sense of the potential wind capacity within each region. If only the highest three wind classes are considered, the vast majority of available wind is found in the Northwest Power region of WECC and the Midcontinent Area Power Pool (as shown in Figure 20).

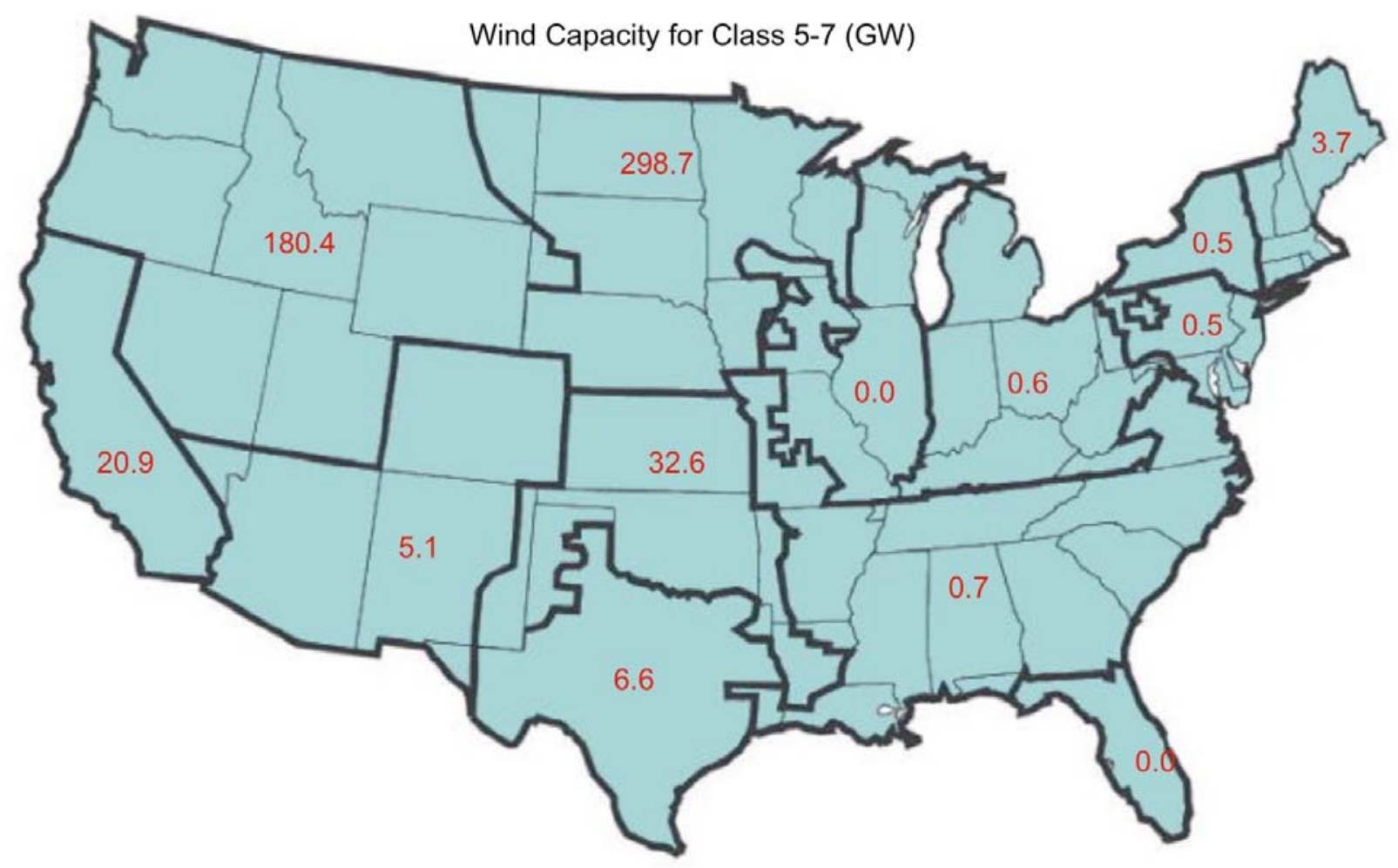

Figure 20. Potential wind capacity by region for Wind Classes 5-7

When the classes of wind used are expanded to include Class 4, then much more of the Midwest has potential wind resources (Figure 21). Most notably, the amounts in ERCOT, SPP (Kansas and Oklahoma) and MAPP increase by four times. However, the capacity to the east of the Mississippi River is still low, much lower than the amount needed to meet a $15 \%$ RPS as shown in Figure 8. This implies that either other renewable energy sources or large amounts of imports from the west will be needed.

The reason for this short fall may be better explained in Table 4. As can be seen, the available wind resources in several regions are significantly larger than the expect development, e.g. ERCOT 3\%, MAIN 3\%, SPP 1\%, WSCC 1\%, and MAPP $0.3 \%$ of the available resource is expected to be developed. As discussed previously this is because of the relative economics with other generation options and the expected demand in the region. 


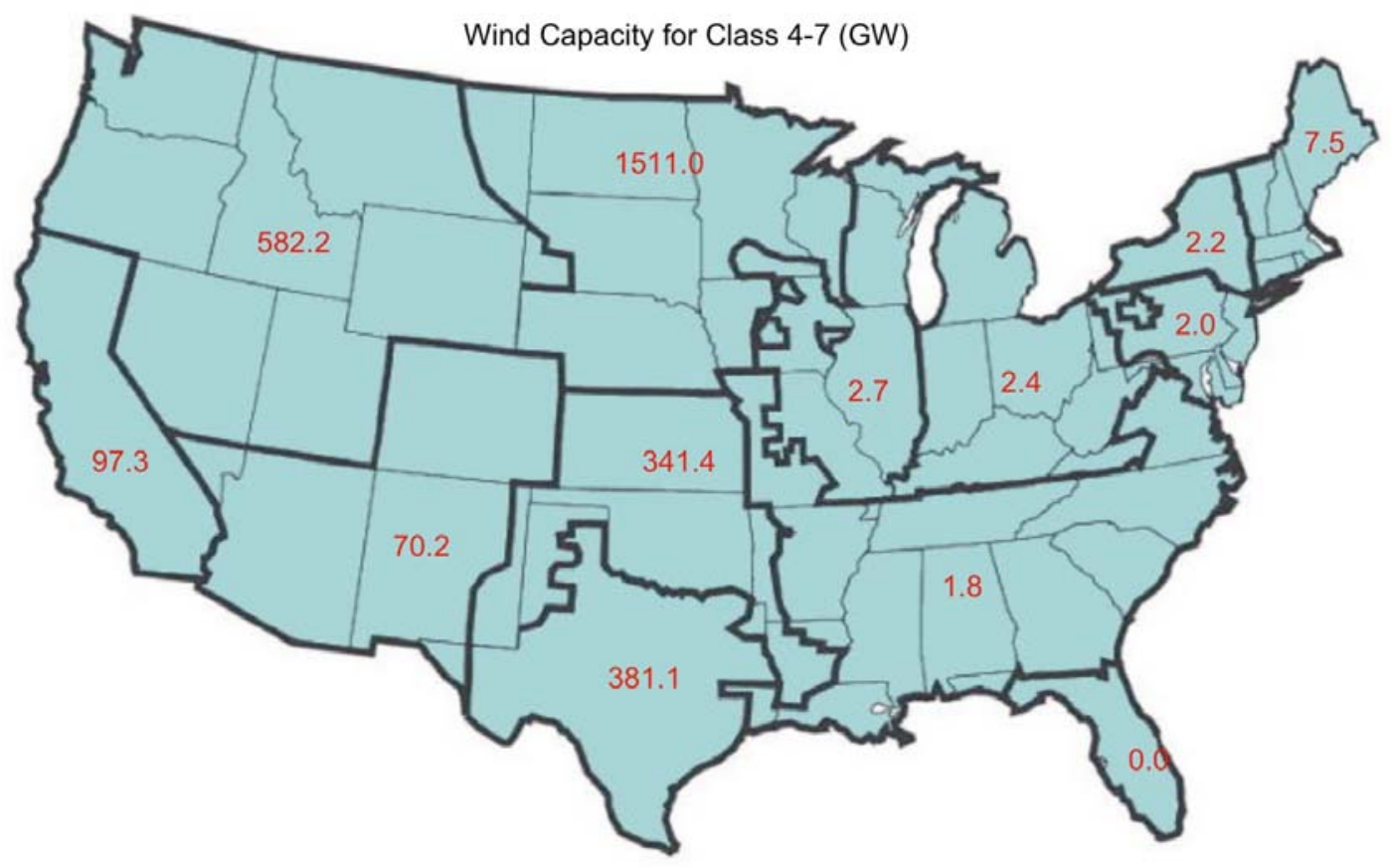

Figure 21. Potential wind capacity by region for Wind Classes 4-7

Table 4. Regional Comparison of Wind Resources and Wind Deployment.

\begin{tabular}{lrrrrrl}
\hline $\begin{array}{c}\text { NERC } \\
\text { Regions used } \\
\text { in EPRI Model }\end{array}$ & $\begin{array}{c}\text { Resource } \\
\text { US (GW) }\end{array}$ & $\begin{array}{c}\text { \% of US } \\
\text { Wind } \\
\text { Resource }\end{array}$ & $\begin{array}{c}\text { 2030 Wind } \\
\text { Deployment } \\
\text { (GW) }\end{array}$ & $\begin{array}{r}\text { \% of Wind } \\
\text { Resources } \\
\text { Harvested }\end{array}$ & $\begin{array}{c}\text { Undeveloped } \\
\text { Wind Resource } \\
\text { Class 3-7 (GW) }\end{array}$ & $\begin{array}{l}\text { Issues for Wind Energy } \\
\text { Transfer to Southeast }\end{array}$ \\
\hline ECAR & 111 & $1.4 \%$ & 17 & $16 \%$ & 94 & $\begin{array}{l}\text { transmission, demand to } \\
\text { east }\end{array}$ \\
ERCOT & 664 & $8.1 \%$ & 23 & $3 \%$ & 641 & $\begin{array}{l}\text { distance, need for dc } \\
\text { links }\end{array}$ \\
MAAC & 9 & $0.1 \%$ & 5 & $49 \%$ & 5 & $\begin{array}{l}\text { resource limits } \\
\text { MAIN }\end{array}$ \\
MAPP & 585 & $7.2 \%$ & 10 & $2 \%$ & 574 & transmission, demand to \\
NPCC/NY & 3,348 & $41.0 \%$ & 12 & $0.4 \%$ & 3,337 & east \\
NPCC/NE & 15 & $0.2 \%$ & 6 & $42 \%$ & 9 & east \\
SERC/FL & 18 & $0.2 \%$ & 6 & $31 \%$ & 13 & resource limits \\
SERC/STV & - & $0.0 \%$ & - & $0 \%$ & - & resource limits \\
SPP & 11 & $0.1 \%$ & 9 & $79 \%$ & 2 & resource limits \\
WSCC/NWP & 1,136 & $14 \%$ & 12 & $1 \%$ & 1,123 & transmission, balancing \\
WSCC/RA & 1,570 & $19.2 \%$ & 18 & $1 \%$ & 1,552 & distance \\
WSCC/CNV & 638 & $7.8 \%$ & 12 & $2 \%$ & 626 & distance \\
Total & 54 & $0.7 \%$ & 20 & $37 \%$ & 34 & distance \\
\hline
\end{tabular}




\section{Conclusions and Next Steps}

Transferring wind energy from windy areas in the Midwest to the Southeast involves not only transmission capacity but also the electricity supply and demand equilibrium in these regions. This interim report has applied the commonly used EIA NEMS, and EPRI NESSIE, energy equilibrium models to better understand these power transfers. This analysis considered regional estimates of capacity expansion and demand for a base case in 2008, 2020 and 2030, and compared the generation mix, renewable deployments, planned power transfers, and meeting RPS goals.

The models provided a first order, regional comparison of future generation capacity and demand. We found that planned transfers of energy between regions with significant wind resources and population centers is less than $10 \%$ of what would be required to meet a $20 \%$ RPS. We also found that the models used are not designed to plan new transfers very much beyond the historical and contractual record.

One key step proposed in the second phase of this project is to model how to increase renewable generation in one region to meet the demand in another. This can be done with changes in NESSIE and using the ORNL ORCED model. Also, simulating different scenarios of renewable deployment and specific power transfer estimates will require modeling at the individual plant and transmission line level of detail. An alternative may be to examine power corridors between regions rather than specific lines and substations. Further work is required in this area. 


\section{References}

American Electric Power (AEP) 2008, Interstate Transmission Vision for Wind Integration. http://www.aep.com/about/i765project/docs/WindTransmissionVisionWhitePaper.pdf

Energy Information Administration (EIA) 2007, Impacts of a 15-Percent Portfolio Standard, SR/OIAL/2007-03, June.

http://www.eia.doe.gov/oiaf/servicerpt/prps/index.html

Energy Efficiency and Renewable Energy 2008, 20\% Wind Energy by 2030: Increasing Wind Energy's Contribution to U.S. Electricity Supply, DOE/GO-102008-2567, U.S. Department of Energy, May.

http://www.nrel.gov/docs/fy08osti/41869.pdf

EPRI Journal, Fall 2007 - Electricity Solutions for a Carbon-Constrained Future - 1016127

EPRI Journal, Spring 2007 - 1015362 and Spring 2008 - 1016422

EPRI Report "Power Generation (Central Station) Technology Options - Executive Summary, October 2008 - 1017443 ”

Pew Center on global Climate Change 2007, States with Renewable Portfolio Standards, August. http://www.pewclimate.org/node/1303 